Article

\title{
The Medieval Synagogue of Molina de Aragón: Architecture and Decoration ${ }^{+}$
}

\author{
Daniel Muñoz-Garrido \\ Independent Researcher, 18012 Granada, Spain; danielmugarrido@gmail.com \\ + This article is dedicated to the memory of Santiago Palomero Plaza (1957-2019), who was Director of the \\ Museo Sefardí of Toledo for many years and worked hard to disseminate the Iberian Jewish heritage.
}

Received: 25 September 2019; Accepted: 25 December 2019; Published: 12 January 2020

\begin{abstract}
The remains of a medieval synagogue, in addition to numerous fragments of plaster decoration, have been found as a result of the excavation work done at the Prao de los Judíos archaeological site in the town of Molina de Aragón (Guadalajara, Spain). These remains suggest that the synagogue was built in the second half of the thirteenth century and that it was refashioned later in the fourteenth century following the same artistic model of the synagogues of Córdoba and El Tránsito. Based on comparative analysis, this article studies the Synagogue of Molina de Aragón in relation to other medieval Iberian synagogues.
\end{abstract}

Keywords: medieval architecture; medieval Iberia; Kingdom of Castile; synagogue; Jewish art; Synagogue of Molina de Aragón

\section{Introduction}

The Jewish quarter of Molina, a town located at the easternmost part of the Kingdom of Castile, was rather important during the thirteenth and fourteenth centuries. The Jewish quarter of Molina had close ties with Cuenca's aljama (Jewish community), $88 \mathrm{~km}$ away, and Daroca's aljama in Aragón, some $50 \mathrm{~km}$ away. Following the end of the Castilian Civil War with the death of King Pedro I in 1369, many towns around the kingdom's frontiers, such as Molina, declared their fidelity to the dead king by free adhesion to the nearest kingdoms of Navarra and Aragón. Some years later these towns were reintegrated into the Castile kingdom, but in order to show its disaffection with the new king, Enrique II de Trastámara, the city of Molina de los Caballeros changed its name to Molina de Aragón.

In 1997, the city council of Molina de Aragón (Province of Guadalajara, Castilla La Mancha) decided to institute a workshop for young people interested in archaeology. The location, chosen for the program by the archaeologists Jesús Alberto Arenas and Juan Pablo Martínez, was a small promontory known as Prao de los Judíos, located next to the town castle. The site, also known in some documents as Castil de los judios, covers almost $1700 \mathrm{~m}^{2}$ and is located at the highest point of the current town center, next to the Puerta de Ahogalobos gate, one of the entrances to the albacar (fortified area) of the medieval fortress (Arenas Esteban and Martínez Naranjo 2004) (Figure 1). The area was significantly modified by building work done in the 1940s during the construction of the $\mathrm{N}-211$ motorway. For this reason, the archaeological site currently has a rectangular ground plan, bounded by sections of the medieval town walls to the north and west and by the motorway to the east and south (Arenas Esteban et al. 2007). 


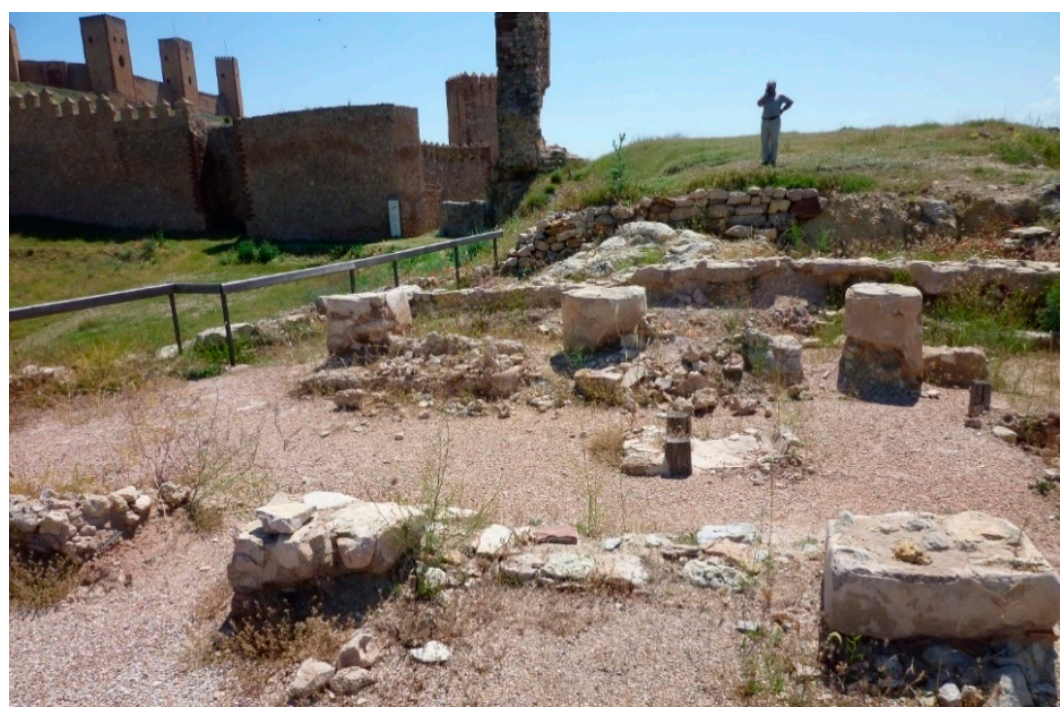

Figure 1. General view of the Synagogue of Molina de Aragón archeological site. Author's photo.

While the remains of Iberian Medieval synagogues are mostly located in big and important cities, Molina is a small town on the border of the kingdom, which makes the archeological remains of its synagogue quite unique. Moreover, these remains are an example of the modestly styled synagogues in rural areas. Additionally, in many cases the synagogues preserved until the present day were founded by important members of the Jewish community who were able to build, decorate, and provide the synagogue with liturgical objects simultaneously (Muñoz-Garrido 2016). As a result of this, these synagogues presented a very unitary appearance regarding architecture and decoration. This has been the conception of medieval synagogues that has prevailed. On the contrary, the Synagogue of Molina stands out as an example of a different type of medieval synagogue with another kind of patronage, more likely to occur in a rural context in which the construction of the synagogue took place in an earlier phase but was refashioned over time. Although the remains found at the archeological site are not easy to interpret, the analysis of those remains provides important key elements for a better understanding of Medieval Iberian synagogues even though just a few of them have survived up to the present day.

The paucity of synagogues that have survived up to the present day is a consequence of the Jewish history in the Iberian Peninsula, but the reason is not just the Jewish Expulsion of 1492. During the Middle Ages, there were various historical events related to the destruction of synagogues before 1492 . The destruction of synagogues as a consequence of violent acts was usually linked to military conflicts. Additionally, episodes of interreligious violence occasionally led to their destruction. The anti-Jewish riots of 1391 are a primary example of this type of violence, because, in many cases, not only were synagogues destroyed, but some Jewish communities also disappeared (Baer 1998).

In a study based on medieval documents, historian Jaume Riera determined that in the Kingdom of Aragón, very few synagogues operated as such for more than a century (Riera i Sans 2006). In fact, today, there are only remains of two Aragonese synagogues: the archeological remains of a synagogue with a very well-preserved ritual bath (Mikveh-מקווז) in Besalú (Girona) dated to the thirteenth century (Lloveras Chavero 2008) and the Synagogue of Hijar (Teruel) from the fifteenth century, which was transformed into the Church of San Antón Abad and identified as a synagogue after recent archaeological and conservation work (Figure 2). In the context of Aragón, construction contracts indicate that the different reasons for the destruction of synagogues included the materials used in their construction, which were common and low cost, such as rock, adobe, and rammed earth. This may have influenced the small amount of archaeological remains found to date (Blasco Martinez 2014). In addition, there are some remains that were part of synagogues, such as the foundation plaques of the synagogues of Girona and Olot (Girona), a wall fountain from Tarragona, a fragment of plaster 
panel from the Synagogue of Xátiva (Valencia), and a small dedication plaque embedded in a house wall in Marlet Street in Barcelona (Cantera Burgos and Millás Vallicrosa 1956).

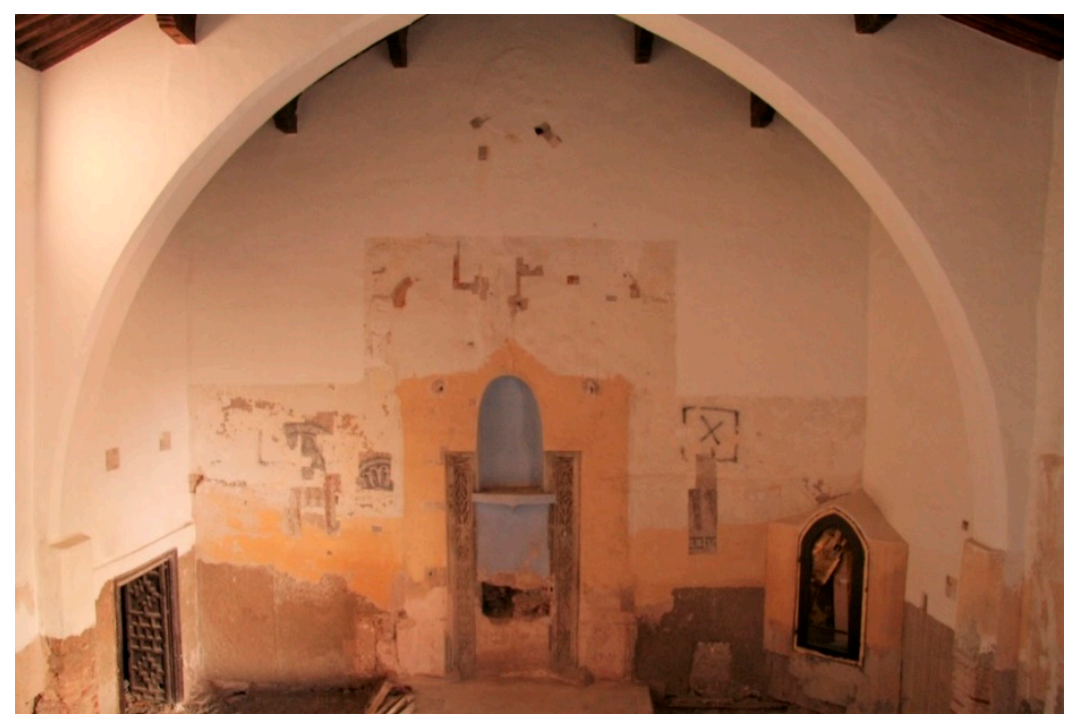

Figure 2. The Synagogue of Hijar. Photo by Antonio Hernández Pardo. Used by permission.

In the Kingdom of Castile, the history of synagogues may have been different, allowing for the survival of buildings originally built as synagogues to the present day. According to Francisco Cantera Burgos's analysis of a poem by Yaaqob Albeneh, until 1391, Toledo had ten synagogues and five religious study centers. The poem was written to commemorate the consequences of that disastrous date. Cantera added two more synagogues to this list, one located in the Barrio de los Caleros and another called the Sofer Synagogue, also known as the Synagogue of Cordobés according to some documents from the fourteenth and fifteenth centuries (Cantera Burgos 1984). In the last few years, Jean Passini identified another two synagogues: the Synagogue of the Golondrinos and the Alley of San Juan de Dios Synagogue (Passini 2011). Therefore, until 1391, Toledo had at least fourteen synagogues, and it could be assumed that this substantial number of synagogues was built over a very long period. The case of Toledo housing numerous synagogues and the fact that most of the Medieval Iberian synagogues surviving today are from Castile outline a particular context regarding the synagogues within this Kingdom.

As a result of violent acts, synagogues were destroyed in Castile as well as in other Iberian kingdoms. Additionally, the urban transformation that started in 1412 after the decree of Catherine of Lancaster ${ }^{1}$ may have been the trigger for the destruction of synagogues. However, during the fifteenth century and after the Jewish expulsion, some synagogues were transformed into hospitals, churches, or even houses. That is the case for the Synagogue of Ibáñez de Segovia, which was transformed into a noble house. ${ }^{2}$ This kind of transformation favored the survival of buildings that were originally built as synagogues.

1 In 1412, Catherine of Lancaster, Queen Regent of Castile from 1406 to 1418, enacted a decree known as the Laws of Ayllón, apparently promoted by Lord Chancellor Paul of Burgos and Dominican Friar Vicente Ferrer, which separated Jews from conversos and Christians. In many cases, the urban restructuration involved the destruction of synagogues as a consequence of moving the Jewish quarter to another part of the city.

2 The original name of this synagogue was also the "Major Synagogue", which might be confused with the former Major Synagogue, today the Church of Corpus Cristi, also known as the Synagogue of Segovia. For this reason, the name of the Synagogue of Ibáñez de Segovia was coined, named after the members of a family that acquired the synagogue and transformed it into their residence. There are documentary records of this synagogue dating back to 1476, and it was probably built after the consecration in church of the previous Major Synagogue in 1419 (Ruiz Hernando 1991). 
The Castilian synagogues that have been dated to around the second half of the thirteenth century present an internal space and architectural features similar to the design of mosques. The Synagogue of Santa María la Blanca of Toledo is perhaps the clearest example of this. Even though we do not have archaeological remains of Al-Andalus synagogues with which to compare, it seems possible that the Synagogue of Santa María la Blanca is inspired by the Andalusian style that was taken to Castile by Andalusian Jews who migrated north. The Al-Andalus Jewish culture did not disappear with the arrival of the Almohads in 1147. The Jewish cultural elite worked and made sure to protect it in order to reestablish it in their new communities in Christian territory (Gerber Satlow 2012). This shared architectural typology has its origin in the Andalusian Omayyad mosque, which has similarities with the basilica (Borrás Gualis 2004). On the other hand, it is important to keep in mind that Jews were permeable to the predominant culture, and in this context, Jewish culture acquired a high degree of Arabization. Perhaps for this reason, an architectural model based on a mosque design was not odd to the Jewish community.

The model that was adopted to build such synagogues was not the luxurious one of the great aljamas' mosques, in which opulence was also a symbol of power, but, rather, was adopted from the simpler and more modest neighborhood mosques with three naves. This typology was more in line with the status of dhimmi that Jews held. This model of three naves could be enlarged by adding side naves in order to reach greater capacity, as in the case of Santa María la Blanca of Toledo, which has five naves. The similarities between this type of synagogue and mosques also explains the fact that some Jewish communities did not find it difficult to adopt and transform mosques into synagogues. This is the case for three mosques, which were transformed into synagogues after the Christian conquest of Seville in 1248, and a fourth one, which was bought in 1327 by Yhuda Abenxabat, Almojarife of Alfonso XI in Seville (Ecker 1997).

Besides the Synagogue of Santa María la Blanca of Toledo, there are others that followed the same model, such as the Synagogue of Segovia and the Synagogue of Santa María la Blanca of Seville. ${ }^{3}$ Santa María la Blanca of Seville was a mosque transformed into a synagogue after the Christian conquest of the city. However, at a certain point in time, the building was deeply transformed into a new synagogue of three naves divided by arches and columns. The date of this reform is imprecise, because, at that time, the construction of new synagogues was forbidden. It may have been that the construction work was masked as a reform by the end of the thirteenth century. That said, it is also possible that the transformation work of the synagogue was related to the earthquake of 1356, which resulted in the repair of several churches in the city. Finally, the synagogue was turned into a church in 1391, which is still active today (Gil Delgado 2013).

The Synagogue of Santa María la Blanca of Toledo has an irregular plan and five naves. The central one is wider and taller than the side ones. The naves are separated by large horseshoe arches that stand on octagonal pillars, which are decorated with plaster capitals that display plant stems that define rhomboid spaces as latticework. From these rhomboids arise prominent volutes and pinecones in relief. The greater height of the central nave allows the introduction of a large frieze formed by decorative medallions, geometrical and vegetal patterns, and cartouches of epigraphy that have disappeared, and in the top part, there is a sequence of blind polylobulated arches. Unfortunately, the decoration of the heikhal wall is missing as a consequence of the renacentist reformation introduced by Cardinal Silíceo in the sixteenth century. It is very possible that the heikhal arch had profuse and rich decoration (Figure 3). The date of this synagogue is often debated by researchers, ranging between the end of the twelfth century and the beginning of the fourteenth century. However, the archaeologist who carried

3 The Santa María la Blanca Church in Seville underwent emergency work to repair some cracks in 1999. In 2010, it was closed to the public in order to carry out a complete restoration, due to the appearance of new cracks. When the workers removed the paintings that adorned the lunettes, copies of the originals by Murillo that were stolen by French Marshall General Jean-de-Dieu Soult, Mudejar arches from the windows of the former synagogue were discovered, debunking the theory that Santa María la Blanca had been built from scratch in the seventeenth century (Gil Delgado 2013). 
out the synagogue excavations between 1987 and 1988 was inclined to place the construction date during the second half of the thirteenth century (Prieto Vázquez 1998). Based on the analysis of the decorative elements, art historian Ruiz Souza dated the synagogue to the end of the thirteenth century or perhaps the early beginning of the fourteenth century (Ruiz Souza 2009).

The Synagogue of Segovia (Church of Corpus Christi) is the most transformed medieval synagogue, because a fire destroyed most of the building in 1899. The restoration was made possible thanks to descriptions and photographs that were taken before the fire. The prayer room is divided into three large naves by horseshoe arches that stand on octagonal pillars decorated with plaster capitals that are very similar to the ones of Santa María la Blanca of Toledo. The date of this synagogue is unknown, but due to its similarities with the synagogues of Santa María la Blanca in Toledo and Seville, it is possible to suggest that it was built during the second half of the thirteenth century. This model of synagogue was also used in the capital of the Kingdom of Aragón. The Major Synagogue of Zaragoza, which is missing, was also divided into naves. The foundation date is unknown, but there are records of this synagogue dating to 1311 . Thanks to a description of the building written in the sixteenth century by Fray Diego de Espés in his Historia eclesiástica cesaragustana, we know that the building was not very large and had three naves divided by marble and jasper columns. The central nave was slightly higher than the side naves. The wooden ceiling had golden decoration and two strips, blue and red, with Hebrew inscriptions that were displayed around the central nave conforming a frieze (Blasco Martínez 1988).

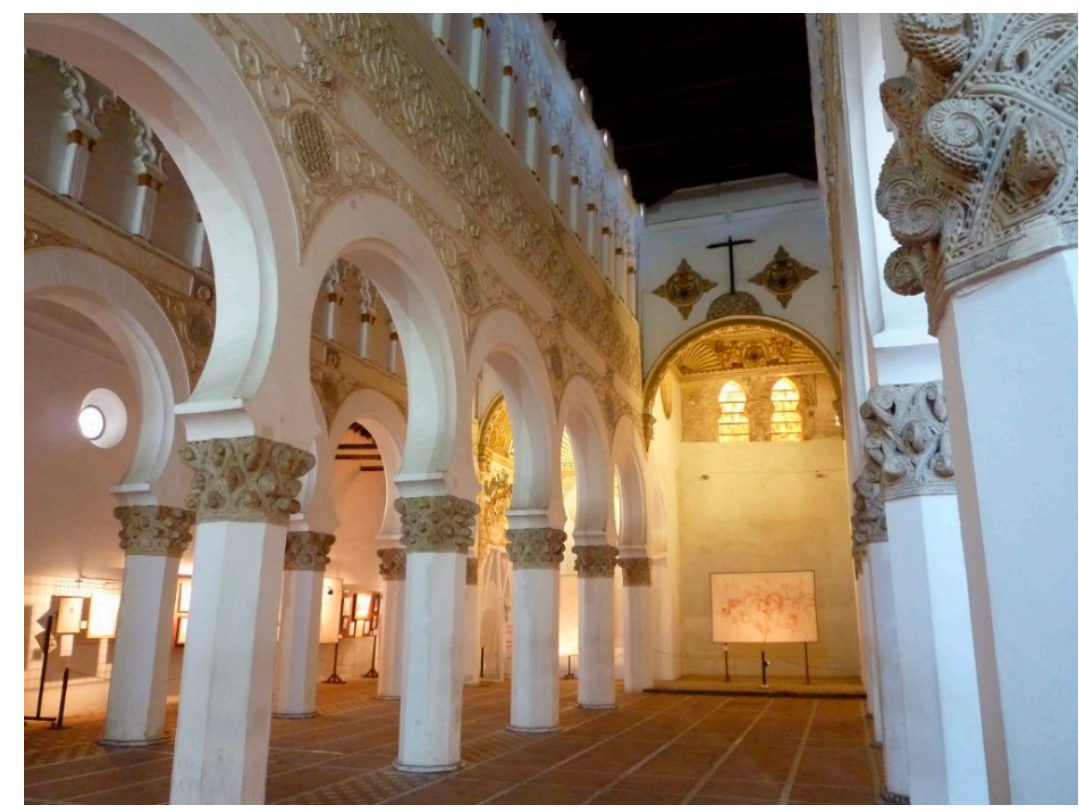

Figure 3. Central nave of the Synagogue of Santa María la Blanca of Toledo. Author's photo.

At the beginning of the fourteenth century, there was a radical change in the organization of the synagogal space. This new model is not divided into naves. Instead, the prayer room is formed by a large and diaphanous hall, decorated with profuse plaster decoration covering large areas in the same line as the ones that can be found in many rooms in the Alhambra Palace of Granada. The decoration of these synagogues mixes elements taken from Nasrid art, such as muqarna with some Christians elements, such as vegetal and heraldry motives. That is the case for the Synagogue of El Tránsito where the coat of arms of Castile and León was part of the decoration, as well as the Samuel ha-Levi family coat of arms. The coat of arms of the Samuel ha-Levi family could be understood as an appropriation of an element taken from the Christian culture (Muñoz-Garrido 2016). The prayer room is preceded by a big vestibule where the women's gallery is located. The most important innovation is the design of the heikhal wall, which is projected like a great facade with three vertical panels. Following the heikhal 
facade model in the synagogues of Córdoba and El Tránsito, the two side panels share decorative patterns, and the central one displays a sebka. In both cases, the composition is completed with a muqarna cornice crowning the facade. The profuse, decorated facade hides the heikhal itself. The central panel in the heikhal-facade model is open in the lower part with arches in order to connect the prayer room with the niche or the small room where the Torah scrolls are kept. The Synagogue of Córdoba is the oldest example of its kind. As the foundation plaque in the right side of the heikhal states, the synagogue was founded in 1315 by the unknown Efraim Wadawa (Figure 4). Some years later, the Synagogue of El Tránsito was founded in Toledo by Samuel ha-Levi, the treasurer of King Pedro I.

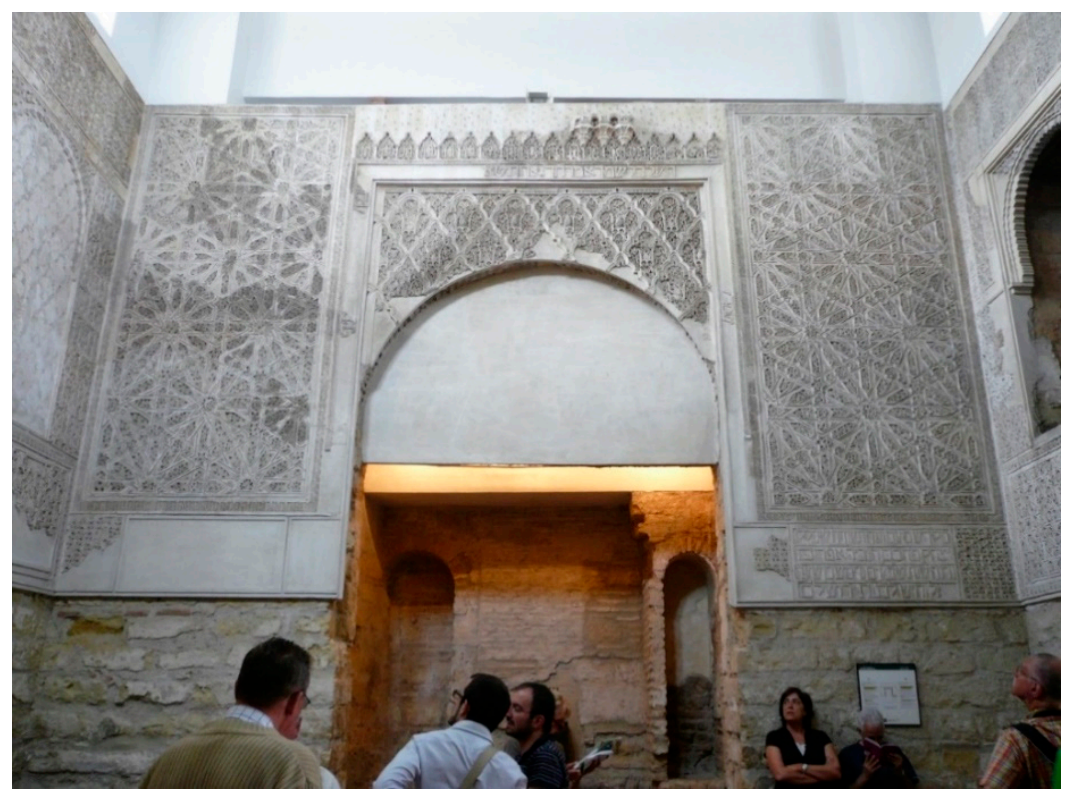

Figure 4. Heikhal of Córdoba Synagogue. Author's photo.

In the Samuel ha-Levi Synagogue, the foundational inscription is divided into two plaques located on both sides of the central panel. The date of foundation is not clear due to the poor state of conservation of the left plaque, which is very damaged. In this kind of inscription, the date is calculated using the numeric value of Hebrew words. The only clear word that was part of the date is טוב (good). After studying the inscription, Cecil Roth suggests the words טוב ליהודים (good for the Jews). The numerical value of all its letters would be 5122 in the Jewish calendar, which is equivalent to 1361-1362 of the Common Era (Roth 1948). This date is also corroborated by another investigation about the decorations of the synagogue, which suggests that the decoration of the synagogue and that of the convent of Santa Clara de Tordesillas were made by the same group of artisans. According to the same study, the plaster work in El Tránsito would have been carried out just after the end of the convent decoration works at some point between 1359 and 1361 (Ruiz Souza 2002). In both synagogues, Córdoba and El Tránsito, the decoration and Hebrew epigraphy are connected to convey a symbolic program that has its clearest reference in the symbolic speech displayed in some rooms in the Alhambra Palace of Granada (Muñoz-Garrido 2017a). Another synagogue that would follow this fourteenth century model was the lost Synagogue of Cuenca, as suggested by the archeological remains and the plaster fragments found in the archeological site (Palomero Plaza 2002).

The fifteenth century brought new trends, and a Gothic architectural model with flamboyant Gothic decoration is very present in the synagogues of this period. The synagogues of Hijar and Lorca have a unique nave made up by diaphragm arches. This design may have been inspired by the popular typology known as Church of the Reconquista, which was in use during the repopulation process in the last period of the Christian conquest of Al-Andalus (Figure 2). 
This article analyses the decoration and architecture of the Molina de Aragón Synagogue in comparison with other aforementioned synagogues. This analysis is based on the study of the architectural remains and the plaster fragments found in the archeological site of Molina de Aragón Synagogue, which are displayed in the Museum of Guadalajara and the Regional Museum of Molina de Aragón. ${ }^{4}$ The analyses of the plaster fragments found in the synagogue explain the evolution of this singular building and among them, especially the plaster fragments dated to the fourteenth century. Following the style of the synagogues of Córdoba and El Tránsito, the stucco work covers large surfaces of the walls, almost as if it were a skin, which is a typical feature of the Nasrid aesthetic style. In this way, the shape and decoration of the pieces found in Molina respond to architectural elements such as doors, arches, and windows. This, in turn, may help us to understand the appearance of the synagogue's walls.

\section{The Prao de los Judíos Archeological Site in Molina de Aragón}

Between 1997 and 2005, an area bigger than $1100 \mathrm{~m}^{2}$ was excavated, reaching a depth of five meters in some places. The material found made it possible to define a timeline of occupation that spanned from the caliphate period (tenth-eleventh centuries) to the fourteenth and fifteenth centuries. The main structure that was found there belongs to a synagogue with an imperfect rectangular floor plan and a prayer room divided into three naves by pillars (Figure 5). During excavations conducted in 2002 at the archaeological site, an investigation was carried out to analyze the characteristics of the subsoil under the synagogue. Based on this study, it was possible to determine that during the reformation of the synagogue, it was filled up with earth and building materials from an older stage of the building. The frescoed fragments of plaster coating display black linear motifs on a red background. The plaster relief fragments that were found were painted in green with simple and modest designs.

Fragments of capitals were found in an upper archaeological stratum. Those capitals were in line with those decorating the former synagogues of Segovia and Santa María la Blanca of Toledo. In addition, panel fragments similar to the plaster decoration displayed in the fourteenth century synagogues were found. All of these facts could allow us to date the construction of the Molina Synagogue to around the second half of the thirteenth century. However, the fragment panels, similar to those of the synagogues of Córdoba and El Tránsito, suggest that it was redecorated later on to adapt its interior to fourteenth-century trends.

In addition to the synagogue, the archeological site contains a complex structure belonging to a public building. This large building has a square floor plan, and it is very possible that the building had at least two stories, doubling its $650 \mathrm{~m}^{2}$ surface, based on some of its architectural elements, such as the sturdiness of its external walls and its thick wood shoring beams. The building's internal layout encompassed both closed and open spaces, such as sandstone-paved corridors, basements, and interior patios. Part of this complex structure belonged to a semi-basement floor set aside for the production of wine, which would explain the trough where the grapes were pressed and the well to collect the must that have been found at the site. In addition to this well, excavated directly into the rock with a capacity of 700 liters, eighteen jugs of fifteen-liter capacity each were found. The storage capacity is small in comparison with other medieval wineries, and therefore, it seems that the quantity produced may have been lower in terms of daily consumption. It is thus possible that this winery produced kasher wine, or so-called "vino judiego" (Jewish wine), for ritual use. ${ }^{5}$ The characteristics of the building

4 I would like to thank Fernando Aguado Díaz, director of the Museum of Guadalajara, the museum staff and the coordinator of the Regional Museum of Molina de Aragón, Juan Manuel Monasterio Cruz, for his invaluable collaboration and hospitality during my research work.

5 This kasher wine, known as judiego or judienco in Spanish and jueu or juich in Catalan, did not require that the grapes be grown or harvested by Jews, but it was a requirement that the rest of the process (pressing, storing, etc.) be done by Jew exclusively. This process differed from the one used by Christians in some oenological aspects. For example, it was forbidden to add water, lime, or gypsum to the wine to make it purer. Wine had a strong ritual role in Judaism, figuring prominently in the celebration of festivals such as Shabbat, Passover Seder, and Rosh Hashanah (Piqueras Haba 2004). 
indicate that it had a public and community function that could also have been related to liturgical aspects and to the synagogue itself. For this reason, it may have also housed other community services, such as the rabbinical court (Arenas Esteban et al. 2007). Moreover, an area for artisanal activity was identified at the site along with a residential area consisting of two dwellings. The urban structure of the place, along with the tight path of the town wall that encloses it, suggests that, at least at some point at the beginning of the fourteenth century, the neighborhood was closed off and segregated from the rest of the town (Arenas Esteban et al. 2007).

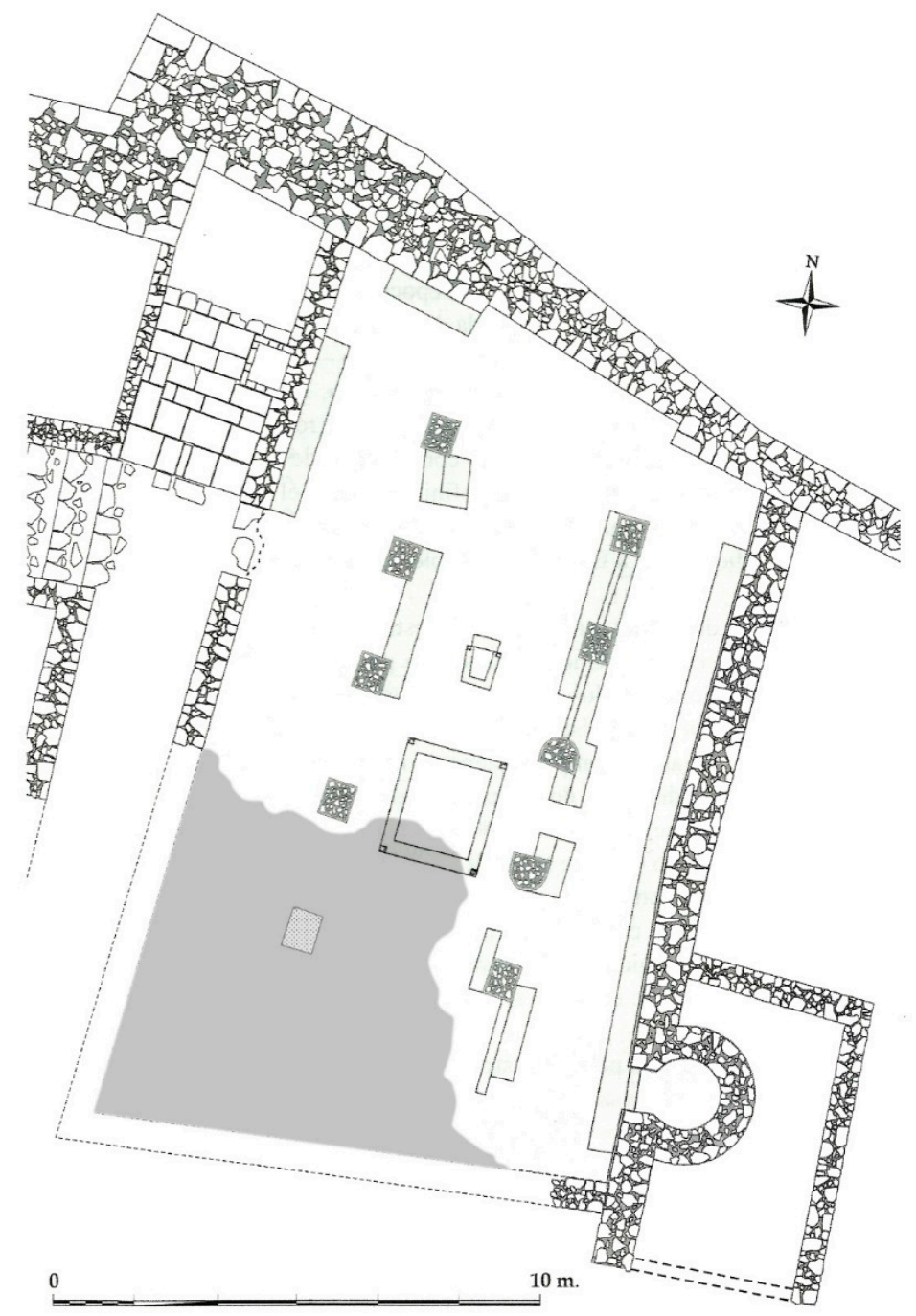

Figure 5. Ground plan of the Synagogue of Molina de Aragón. Drawing by Fernando Lechuga, based on a plan of Jesús Arenas. Used by permission.

The high amount and quality of the ceramic remains found at the site demonstrate that the Jewish community in Molina was very prosperous during the fourteenth and early fifteenth centuries. The ceramics found were not only items for daily use, such as utensils for preparing and serving food, but also high-quality tiles decorated in the islamicate style, golden tiles from Manises, and glazed ceramics from Guadalajara and the workshops of Teruel and Valencia. The ceramic materials are illustrative of the trade relations between Molina de Aragón and other areas at the time. The most notable items found include highly decorated metallic pieces, such as buckles, door locks, and two bronze straight pins with a coral head and pâte de verre. Other important objects of daily use that were found are a bone comb, a limestone mortar, an ivory dice, a silver ring with the Hebrew inscription 'Shalom Oro Vida', a lacquer stamp with the inscription 'Moshé bar Shamuel Habibas', a bronze coin 
with a hexagram on one side and a menorah with an illegible inscription on the other, possibly used as a talisman (Arenas Esteban and Martínez Naranjo 2004), fragments of two tiles from Teruel belonging to a chanukkiah, and a small iron knife with a polished bone handle (Arenas Esteban et al. 2007).

Prao de los Judíos and its synagogue seem to have lost their stability as a settlement in the mid-fifteenth century. The archaeological remains suggest that the site was abandoned before 1492 . The state of preservation of the plaster, which still has its polychrome, seems to indicate that the building collapsed suddenly. If the site was abandoned gradually, the state of the ruins would be worse than it is presently. The building seems to have collapsed as a result of an attack on the Jewish quarter that aimed to destroy the synagogue. This seems very possible due to the suddenness of the destruction and the strike marks and scratches on some of the plaster fragments (Arenas Esteban 2017). It is unknown which were the effects of the anti-Jewish riots of 1391, but it is very possible that, as in the case of Cuenca, the aljama of Molina suffered serious damage (Arenas Esteban and Castaño González 2010). In the context of this violent and intentional destruction, it is very probable that stucco fragments were disseminated throughout the prayer room.

There are just few extant documentary references to the Prao de los Judíos that provide indirect information about the synagogue dating back to the late fifteenth century, when the building had already been destroyed (Arenas Esteban and Castaño González 2010). These documents refer to Judaizing conversos and crypto-Jews. The population of Jewish conversos in this area was quite high during the fifteenth century, and more than 120 Inquisitorial files against Judaizing neighbors in Molina are held at the National Historical Archive in Madrid and the Cuenca Diocesan Archive. In 1495, the trial of Juan Fernández Greson took place. During this trial, Doña Olalla, a witness for the prosecution, stated that "yva cada mañana a Castil de Judios, que fue antiguamente synoga de judios, e que non sabe este testigo lo que alli se hazía"6. At the same trial, another witness of the prosecution, Yoçé Pachel the elder, a Mudejar man who worked for Mose Aben Xuxen, testified. This witness declared that, 35 years earlier-around 1460 - he saw Juan Fernández praying in the company of two Jews and other conversos:

Que vido este testigo desde una ventana de su tio Abrayn Pachel commo en casa de Juan Gallego, Vezino de la dicha villa, estava don Mose Aben Xuxen [judío], arrendador, que posava alli de continuo. E este testigo vio ayunar el Ayuno Mayor al dicho judio, e con el a Juan Ferrandez Greson e a otra personas cuyo nombres dixo, a los quales vio ayunar el dicho Ayuno Mayor, e estar descalços en la posada del dicho judio. E vio commo estovieron alli todo el Dia Mayor justamente fasta la noche, salida el estrella, que vido este testigo a Ysaque, Judio, criado del dicho don Mose, commo tanio un cornezuelo tres vezes, e vio commo los suso dichos hizieron todos oraçion, e despues de fecha çenaron alli todos. ${ }^{7}$

The fact that Doña Olalla talks about the synagogue in the past tense, as if it were no longer standing, and Yoçé Pachel's description of the rite of sounding the shofar for Yom Kippur in the house of Juan Gallego instead of in the synagogue, suggest that the building had already been destroyed at least before 1460. Other Inquisitorial records demonstrate that the Castil de los judios neighborhood continued to be inhabited and that its inhabitants were primarily conversos. This conclusion is extracted from the confession of Juana Fernández la Brisela, who asserted" que las que bebian en el Castil de Judios venían cada sábado compuestas a ver a las de abaxo. Y que su madre deste testigo dezia: "mirad quales vienen estas judias compuestas" ${ }^{\prime \prime}$

6 "Every morning he went to Castil de judios, which used to be a synagogue, and this witness does not know what he did there" (Cantera Montenegro 1985).

7 "From a window in the house of his uncle Abrayn Pachel, this witness saw [the Jew] Mose Aben Xuxen, the landlord who often stopped by there, in the house of Juan Gallego, a neighbor of said villa. And this witness saw this Jew do the Great Fast and be barefoot in the house of said Jew, and saw how they were there throughout the Great Day until the star came out at night. This witness saw how the Jew Ysaque, the servant of said Mose, sounded the little horn three times and saw how all of them prayed, and once all of them dined there together" (Cantera Montenegro 1985).

8 "Those who lived in Castil de judios would come every Saturday to visit those below and the mother of this witness would say, 'look at how elegant those Jewish women are'" (Cantera Montenegro 1985). 
With the passing of the years, the memory of the Jewish presence in Prao de los Judíos faded. Fortunately, archaeology has recovered this legacy, allowing its preservation despite the lamentably neglected state of this valuable and compelling site.

\section{The Synagogue in the Thirteenth Century}

The Synagogue of Molina de Aragón had an almost rectangular floor plan, approximately 9.80 meters wide by 16.40 meters long. The prayer room was at least 160 square meters, which gives it a capacity for approximately 50 people seated (Arenas Esteban and Castaño González 2010) (Figure 5). The southern wall and part of the western wall are gone, which makes difficult the correct interpretation of the interior space of the synagogue. The orientation of the three naves, which are divided by pillars, is north-south. The northern wall of the synagogue adjoins one of the sections of the town wall. ${ }^{9}$ This precise location, next to the town wall, was common during the thirteenth and fourteenth century due to the fact that Jewish quarters were often located on the outskirts of the towns and, therefore, part of the town wall was always around part of the perimeter of the Jewish quarter (Riera i Sans 2006). The main entry was quite possibly located in a hollowed out opening, of which remains are located on the western wall. ${ }^{10}$ This main door was preceded by a small widening of the street, like a small plaza (Arenas Esteban and Castaño González 2010), which contained a water basin (Arenas Esteban 2017) that could be used to perform ablutions before prayers.

The pillars that divided the prayer room into three naves (Figure 1) were crowned by capitals quite similar to those that decorate the synagogues of Segovia and Santa María la Blanca of Toledo (Figure 6). For the archaeologist Jesús Esteban, the lack of bricks among the synagogue remains indicates that there were no arches over the pillars in the prayer room. He also suggests that the upper part of the central nave was supported by wooden beams that rested on the pillars (Arenas Esteban 2017). However, this architrave system seems unlikely, given that all the other similar synagogues have arches instead. There is no evidence of the existence of arches, but neither is there evidence of wooden beams. Moreover, the absence of arches would have affected the height of the central nave, making it impossible to redecorate the heikhal (Torah ark- היכל) following the fourteenth-century model. This type of ark was organized into three large vertical panels, which required a nave of a certain height, as the ones that can be found in the synagogues of El Tránsito and Córdoba (Figure 4). This redecoration is described in more detail in Section 5. Furthermore, archaeological evidence does reveal the existence of plaster benches inside the synagogue. The perimeter of the prayer room had a bench running along the walls, and other benches were located in the spaces between the pillars, although some of these spaces may have been left empty to allow people to move from nave to nave and to facilitate access to all the benches of the synagogue (Figure 5).

The central nave had a rectangular structure of 2.10 meters long by 1.30 meters wide. This structure has been identified as the tevah (תיבה) for two reasons, firstly, due to its location in the central nave and, secondly, because of its shape, which still preserves the impressions from the wooden posts that held the platform up on its corners (Arenas Esteban and Castaño González 2010). Next to the tevah, the remains of another structure were found. This will be discussed below with regard to the location of the heikhal (Figure 7).

9 The synagogue in Segovia also adjoined the city wall, leaving its ark boxed in between the synagogue and the city wall (Cantera Burgos 1984).

10 In synagogues with a basilica floor plan, the door is usually located in one of the two sides, unlike in churches and mosques, where the main door is usually opposite to the altar or mihrab (Palomares Sánchez 2009). 


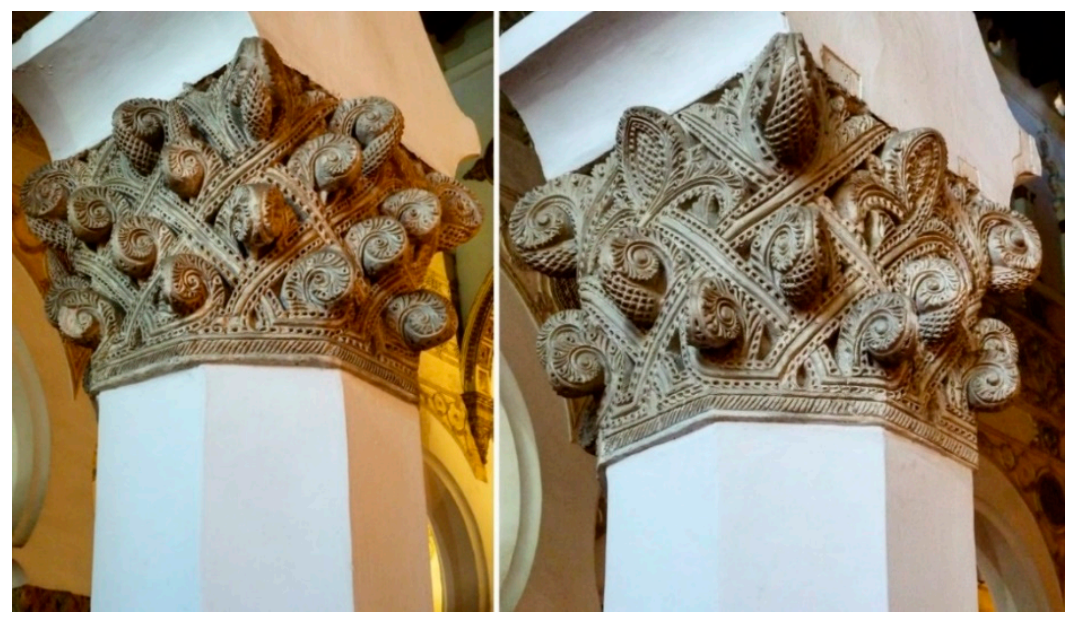

Figure 6. Two capitals of the Synagogue of Santa María la Blanca of Toledo. Author's photo.

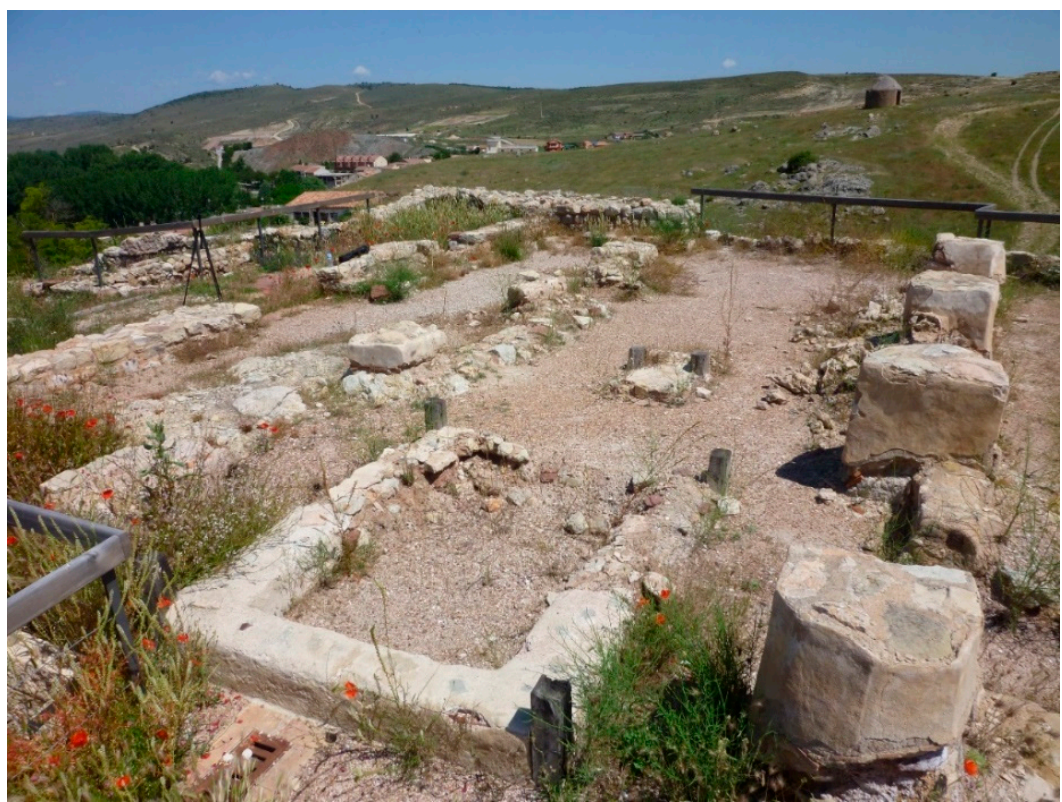

Figure 7. General view of the Synagogue of Molina de Aragón archeological site. Author's photo.

The study of the fragments that belonged to the capitals of the synagogue and their comparison with the capitals of Santa María la Blanca of Toledo allow us to identify the existence of at least four or five different models of capitals. Some of the fragments share the model of the capital but with small differences in their patterns (referenced in Figures 8 and 9 with the letters a and b). The indeterminate number is due to the fact that two of the proposed models of capitals, the second and the third ones, could be indeed part of the same capital. The fragments are too small to positively assert that they belonged to two different models. However, they seem to have formed parts of different capitals, because, as in the case of the Synagogue of Santa Maria la Blanca in Toledo, the capitals were placed in pairs, facing each other, across the synagogue's naves. ${ }^{11}$ Unfortunately, as a consequence of the violent

11 In the Synagogue of Santa María la Blanca of Toledo, the capitals are very similar. They display a complex patron made up by pinecones and plant stems that define rhomboid spaces. However, the general model of the capitals changes with small differences as the naves approach the heikhal as some sort of an aesthetic play (Figure 6). 
destruction of the Synagogue of Molina, the stucco fragments were dispersed throughout the prayer room. That is the reason it is not possible to determine which capital belonged to each pillar.

Capital 1-a was formed by a necking ring circled by a palmette border. The body of the capital was decorated with acanthus leaves in high relief. Capital 1-b presents different motifs around the border, which, in this case, has a plaited design. The Synagogue of Santa María la Blanca of Toledo has a capital with quite similar acanthus leaves. Moreover, the design of capitals 1-a and 1-b from Molina are similar to the one found in the Toledo Synagogue, which gives us an approximate idea of what the capital of the Synagogue of Molina might have looked like (Figure 8). Only two small fragments from capitals 2-a and 2-b were found, belonging to the borders that ran under the body of the capital. This border is divided into two levels. On both capitals, the lower level is decorated with palmettes, while the upper part of 2-a is decorated with a Greek key pattern and 2-b is decorated with a plaited border (Figure 8).

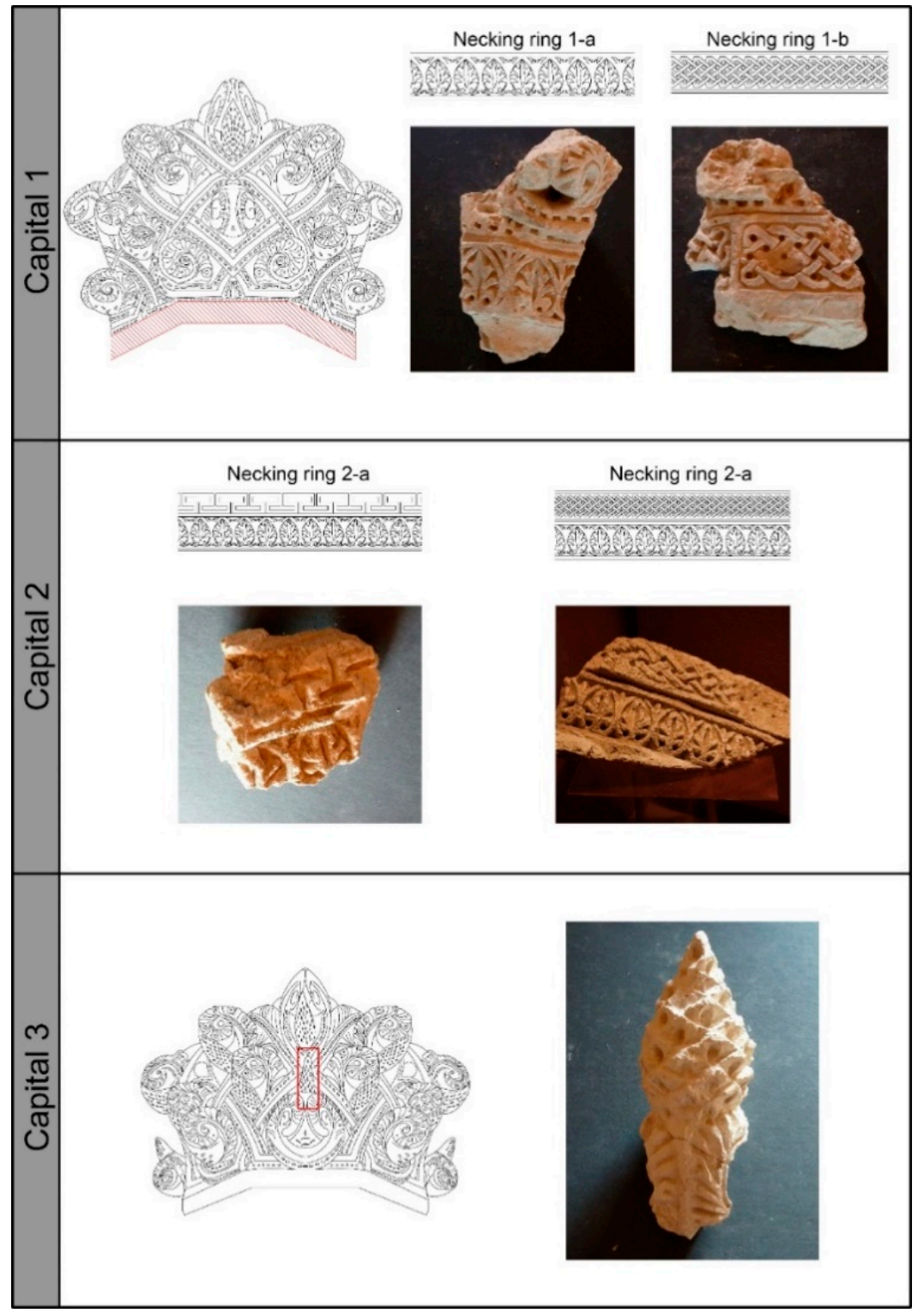

Figure 8. Fragments and possible reconstruction of the capitals of Molina de Aragón Synagogue. Created by author.

The only remnant of a small fragment from capital 3 is decorated with acanthus leaves from which a pinecone emerges in high relief (Figure 8). The Santa María la Blanca Synagogue of Toledo has 
some capitals with similar pinecones, which provide an idea of how the capitals of the Synagogue of Molina would have looked. On the other side, the fragment that corresponds to capital 4 is quite large. It is possible to deduce that this was a large capital, much larger than the others that decorated the Synagogue of Molina and even slightly larger than the ones found in Santa María la Blanca. The fragment belongs to the body of the capital and is decorated with latticework formed by plant stems that define rhomboid spaces of differing sizes. Inside these rhomboids, pinecones can be found in mid to low relief. The Synagogue of Santa Maria la Blanca has a similar capital that allows us to imagine how the capitals of the Synagogue of Molina might have been (Figure 9).

Capitals 5-a and 5-b are particularly striking. Not only do they not look like the other ones found in the synagogue, but they also have no parallels in other medieval synagogues. The fragments show an original capital in the form of a palm tree that alternates some elements in the two sub-models (a and b). Capital 5-a has a necking ring under a palmette border, while 5-b has a necking ring with a Greek key pattern border (Figure 9).

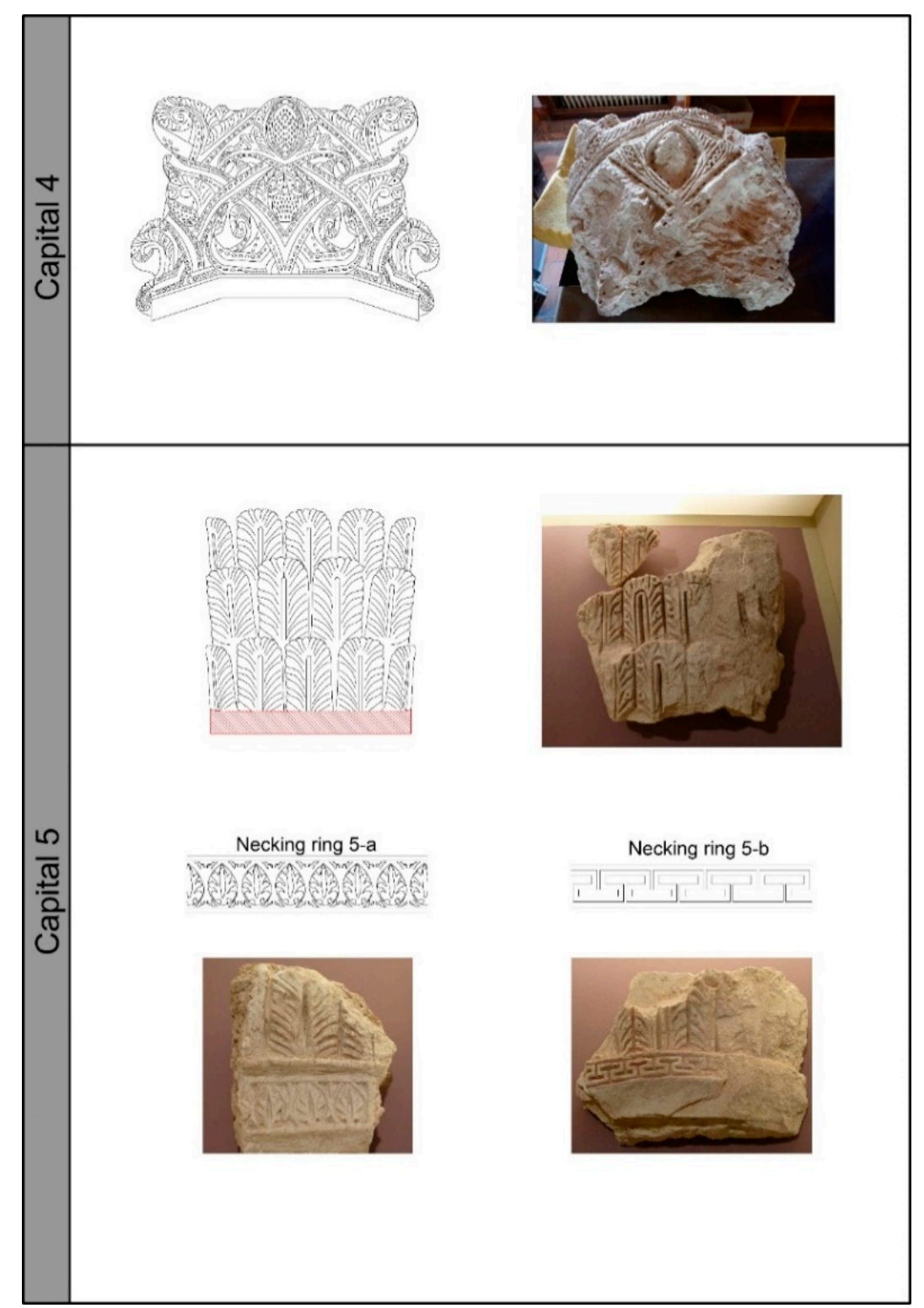

Figure 9. Fragments and possible reconstruction of the capitals of Molina de Aragón Synagogue. Created by author. 
In summary, the Synagogue of Molina shares many architectural and decorative similarities with other synagogues from the second half of the thirteenth century. For instance, the interior space was divided into naves, and the pillars that divided the naves were decorated with plaster capitals in the same style as the ones of Santa María la Blanca of Toledo and the Synagogue of Segovia. These capitals were not modified during the fourteenth-century redecoration, and they were preserved until the destruction of the synagogue.

\section{The Location of the Heikhal (Torah Ark)}

The fact that the southern wall of the synagogue is missing, makes it difficult to interpret the internal appearance of the building and the location of the heikhal, in other words, the place toward which the congregants prayed. Archaeologist Jesús Arenas has suggested over the years that the ark might have been on the eastern wall. His argument not only considers the traditional location of the ark on the eastern wall of a synagogue, but also rests on the fact that the two pillars between the tevah structure and the eastern wall are different from the rest, in addition to the fact that large decorative fragments were found in this area (Arenas Esteban 2017).

However, other elements in the synagogue suggest a different location for the heikhal. The eastern wall has a running bench that breaks up completely the organization of the space in a Sephardic-style synagogue. Moreover, considering that the synagogue was destroyed intentionally, it is possible that the decorative fragments were scattered around the room after being pulled off the walls. Furthermore, it is quite likely in this context that, after the destruction of the synagogue, some neighbors went to the building in search of items that could be reused, which probably contributed even more to the dispersion of materials around the site. ${ }^{12}$

It should not be taken for granted that synagogues had an exact, fixed orientation toward the east, and indeed, many other houses of worship were not oriented toward Jerusalem. The synagogues of Santa María la Blanca of Toledo and El Tránsito, the Synagogue of Córdoba, and the synagogue in Lorca have different orientations between north and east, while the Synagogue of Segovia is oriented toward the south. The most unique one is the Synagogue of Hijar (Teruel), which was oriented toward the southeast (Hernández Pardos 2019). Moreover, the research carried out by Jaume Riera, based on medieval documentation, shows that the synagogues in the Kingdom of Aragón did not follow any predetermined orientation (Riera i Sans 2006). The construction of the synagogue was subjected to many restrictions that affected everything from the place where it could be built to its size and height. However, it seems that practical architectural sense prevailed over the ideal model of the synagogue. In the case of the Synagogue of Molina, the remains of the tevah and the arrangement of the benches around the central nave correspond perfectly to the organization of the interior of a Sephardic synagogue in which worshippers were arranged in parallel to an axis defined by the tevah and the heikhal. This would mean that the ark was located either on the north wall or south wall.

Unfortunately, the south wall is gone, and with it, the possibility to determine whether the ark was located there or not. However, the position of the tevah indicates that the ark must have been on the north wall, because the reading tower is usually slightly off-center and the tevah is a bit closer to the wall opposite the $\operatorname{ark}^{13}$ (Figures 5 and 7). The possibility that the heikhal was located here is reinforced by the fact that the thickness of the north wall was lessened to create a small rectangular niche (Figures 5 and 10). Compared with the synagogues of Santa María la Blanca of Toledo and Córdoba, this ark would have been a small one, but its rectangular form and measurements are similar

12 In contrast with the Synagogue of Molina, the Synagogue of Lorca was abandoned, and its upper tiers still contain remains of roof tiles and even fragments of metal and small chains from the lamps that hung from the ceiling (García Sandoval 2009). The absence of this type of material at the Molina site reinforces the idea that there was a violent destruction, and subsequently, the remnant materials were reused. This process would have dispersed, even more, the decorative elements around the site.

13 The tevah was usually located in the center of the synagogue in order to make it visible for as many participants as it would be possible (Mann 2017). 
to those of the ark of the Synagogue of Lorca of 0.85 meters deep by 1.16 meters long (Figure 11) (Gallardo Carrillo and González Ballesteros 2009).

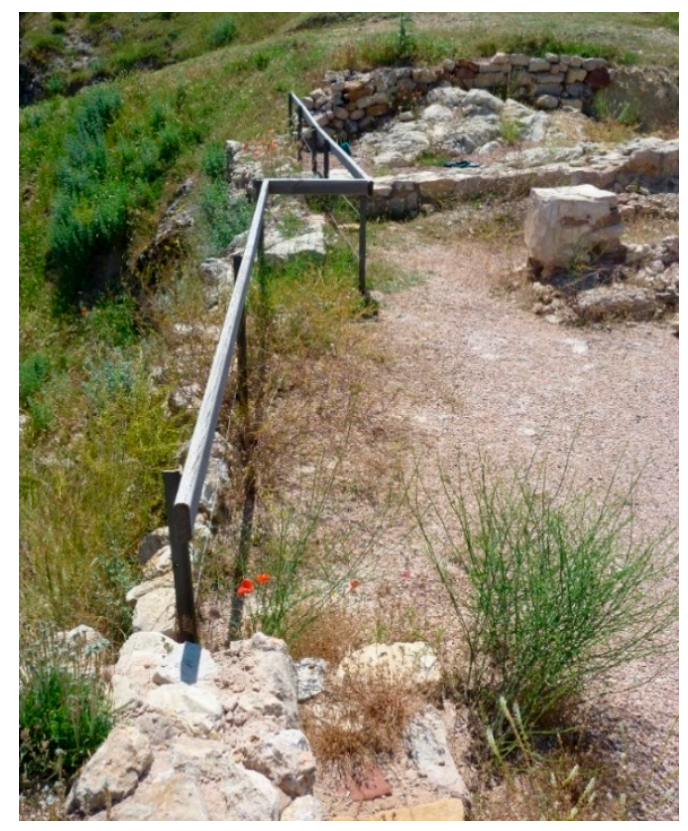

Figure 10. Detail of the north wall at the Molina de Aragón Synagogue archeological site. Author's photo.

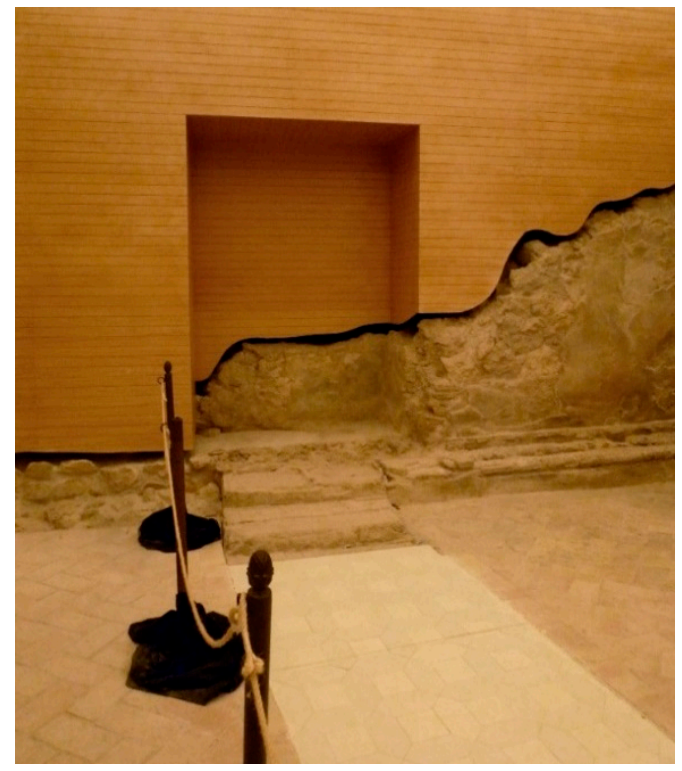

Figure 11. The heikhal of Lorca Synagogue. Author's photo.

The remains of a small structure near the tevah, which still preserves the impressions of two wooden posts and which is aligned with the tevah-heikhal axis, are pieces of evidence that reinforce this interpretation of the interior space of the synagogue (Figure 12). This structure could have belonged to the migdal etz (מגדל עלץ, 'tower of wood') or alminbar (אלמנבר), as it was called in many medieval documents because of its similarity to the characteristic pulpit of mosques. This platform was used by the rabbi to deliver the drasha (sermon-דרשה) and was usually located between the heikhal and the tevah, as in the remains of the synagogues of Hijar and Lorca (Figure 13). This location is also corroborated by Christian artworks that recreate scenes from the life of Jesus. During the Middle Ages, Christian, 
converso, and Jewish artists drew scenes of their daily lives to represent biblical scenes in which Jews from the Scriptures are represented as medieval Jews and the Temple of Jerusalem as a synagogue in an attempt to make the scene more authentic (Mann 2010). One altarpiece panel now held at the Metropolitan Museum of Art in New York, which represents the scene of 'Jesus among the Doctors', 14 recreates the interior of a synagogue that is startlingly similar to the remains of the synagogues of Hijar and Lorca (Figure 14). In this particular panel, the synagogue is used as a model to represent the Temple of Jerusalem, and the medieval Jews are the archetype for their biblical ancestors. The panel shows the inside of a Gothic building. In the foreground, the prayer room is dominated by a structure with steps, quite similar to the minbar of a mosque, on which young Jesus stands. Behind him is the tevah, raised on columns, and the side benches are filled with Jews consulting books.

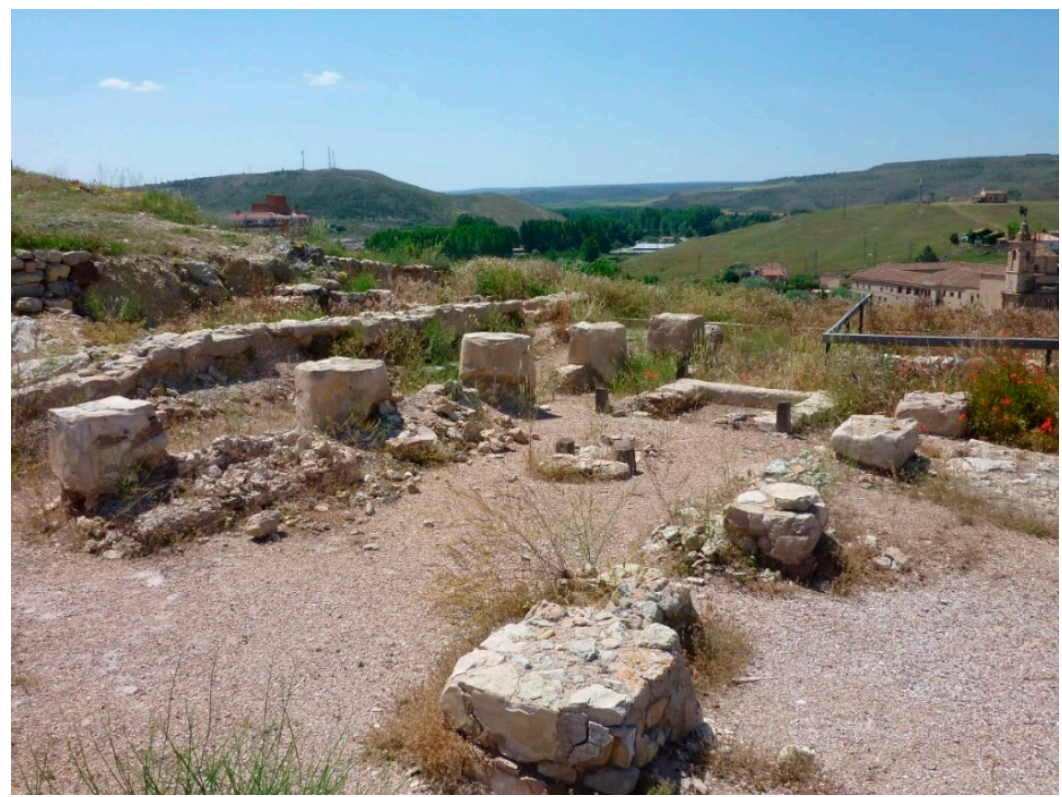

Figure 12. View of the remains of the tevah of Molina de Aragón Synagogue. Author's photo.

This evidence suggests that the remains found between the tevah and the heikhal in the Synagogue of Molina belong to an alminbar or migdal etz. That would corroborate the supposition that the heikhal was on the north wall, because that is the case for the synagogues of Lorca and Hijar, the alminbar was aligned with the tevah-heikhal axis. This kind of pulpit began to disappear from synagogues after the Middle Ages, ${ }^{15}$ making difficult the interpretation of the archaeological remains of some synagogues, because no similar elements are found in Sephardic synagogues from later centuries.

It seems that the migdal etz or alminbar had antecedents in the synagogue architecture prior to the Middle Ages. Some synagogues contained wooden platforms that had a different purpose from the one of the tevah. Similar to church pulpits, this piece of furniture would have been taken from mosque furnishings, where the minbar ${ }^{16}$ is used by the imam to give his sermons (khutbah). This origin could explain the similarity between the form of a mosque minbar and a migdal etz or alminbar. The Migdal etz

14 I would like to thank the late Vivian B. Mann $z^{\prime \prime} 1$ for the opportunity she gave me to assist in the creation of a catalogue for the exhibition Uneasy Communion, held in 2010 at the Museum of Biblical Art in New York. Thanks to this experience, I became aware for the first time of this altarpiece panel.

15 In the eighteenth century, the pulpit was brought back into the synagogue, although the new version was modeled after church pulpits (Krinsky 1985).

16 The minbar is always positioned to the right of the mihrab and consists of a staircase, usually with handrails, leading to a small platform, which is often crowned by a cupula. Its origin was a similar platform in Muhammad's house in Medina, which he used to give his speeches and be more easily heard by his audience. Traditionally, the imam reads or speaks one step below the top of the platform, which is symbolically reserved for the Prophet (Frishman 1994). 
was not as holy as the tevah, where the Torah scroll were placed, which means that it could be used for more secular purposes. Community leaders addressed their communities from this stepped platform, and when a non-Jew needed to address the group, this would happen from the Migdal etz. For example, when representatives of the civil, royal, or ecclesiastical authorities had to make an announcement or notify the community about some matter, they would use the Migdal etz (Ben-Dov 2009). According to some sources, certain Christian sermons to which the Jews were obliged to listen, were given from the migdal etz or alminbar at the synagogue (Kogman-Appel 2011).

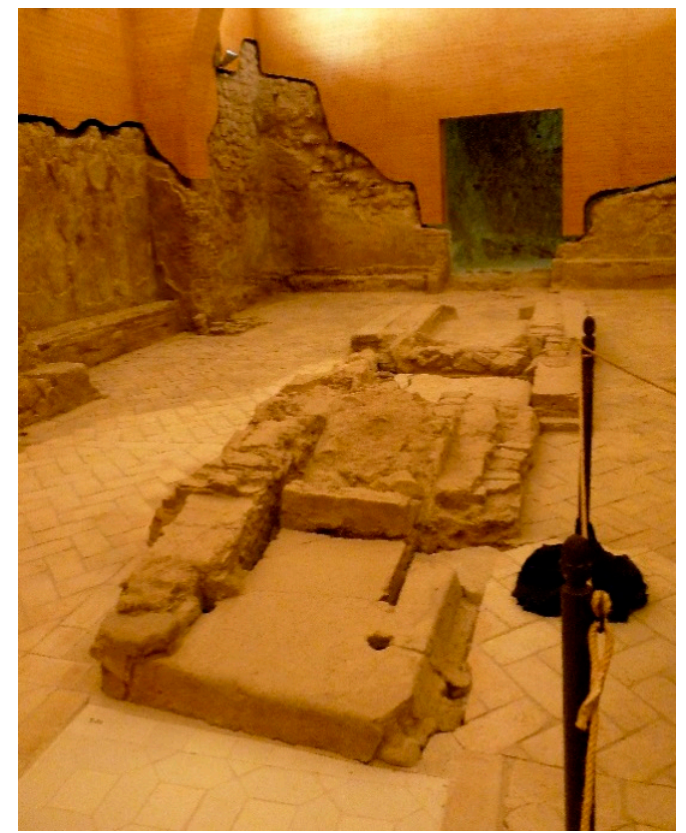

Figure 13. View of the remains of the tevah of Lorca Synagogue. Author's photo.

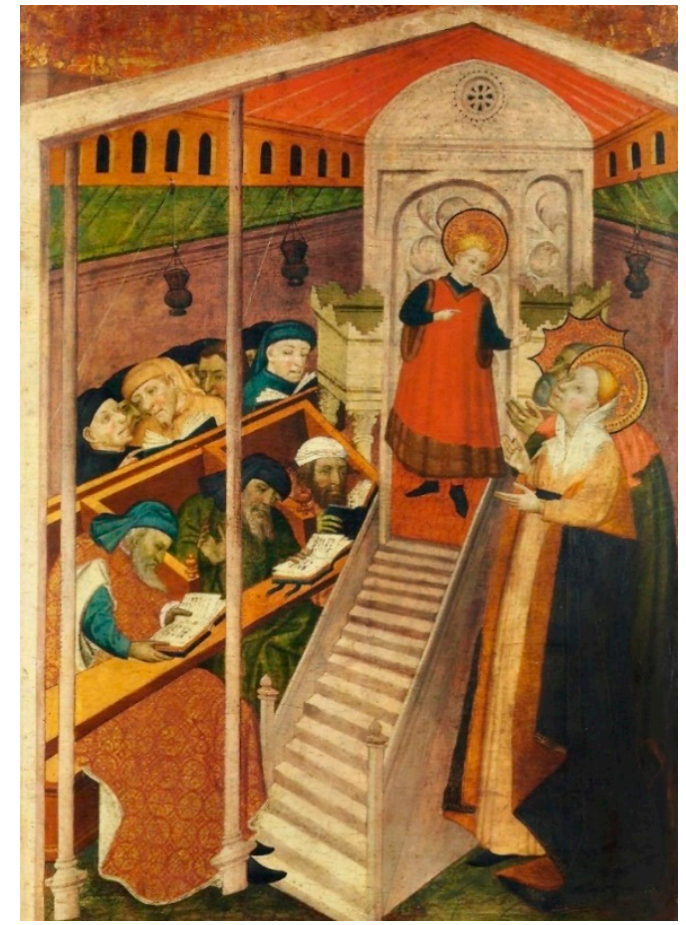

Figure 14. Jesus among the Doctors, panel from a Spanish altarpiece, early fifteenth century. Courtesy of Metropolitan Museum of Art. 
In the last few years, the interpretation of the remains of the synagogues has been controversial, because the idea of east-oriented synagogues is very present among some scholars, and therefore, it is difficult to conceive it being otherwise. Synagogues as large and rich as El Tránsito or Santa María la Blanca of Toledo contributed to create and build that concept, but it is important to understand that those are synagogues built in big cities and founded by important members of the community, which makes them an exception. The presence of the alminbar in the synagogue helps to interpret the internal space of medieval Iberian synagogues. As it is shown in the aforementioned panel of the Metropolitan Museum and the archaeological remains of Molina, Hijar, and Lorca, the alminbar was attached to the tevah that was placed in the tevah-heikhal axis.

\section{The Synagogue in the Fourteenth Century}

Some of the decorative fragments found in the Synagogue of Molina belong to the fourteenth century. The analysis of these fragments provides information about the redecoration done inside the synagogue. Among all the plaster pieces that have been found, one of them stands out because of its size and its epigraphic decoration. This specific piece is currently on exhibition at the Museum of Guadalajara. In the museum, the fragment is exhibited vertically, according to the direction of the Hebrew inscription in order to make it easier to read. However, the position of the pinecone in the corner of the inscription line suggests that the original position of the piece was a different one. By turning the panel to a horizontal position (Figure 15), it is possible to see that the fragment contains the joint where the two panels would have met. That specific point was separated by a line of Hebrew inscription. This composition can be understood as part of a fourteenth-century heikhal facade model. Thus, most of the piece belongs to the right panel, and the Hebrew line framed the central panel of the heikhal facade.

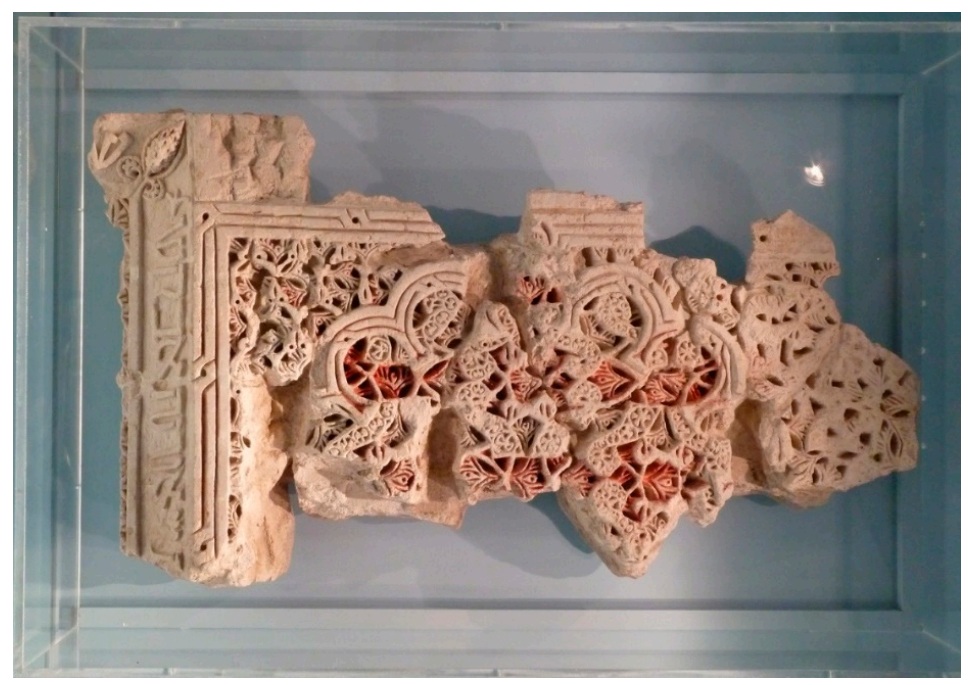

Figure 15. Decorative panel of the heikhal of Molina de Aragón Synagogue. Author's photo.

The decoration of the heikhal in the synagogues of Córdoba and El Tránsito is organized into three vertical panels (Figures 4 and 16). The fact that both synagogues use the same facade model suggests that this was the trend during the fourteenth century. Apparently, this design was not limited to synagogues decorated with plaster relief. According to a responsum written by Asher Ben Yehiel, ${ }^{17}$ the tripartite arrangement was also done using two mats hung on either side of the ark. As researcher

17 In a responsum, Asher Ben Yehiel was asked about some mats that were going to be hung on either side of the ark. The iconography of these mats aroused some suspicion regarding whether they could lead to idolatry if they were hung inside the synagogue (Mann 2004). 
Purificación Marinetto has observed, covering a wall with textiles is closely related to wall tiling and plaster relief when they feature a textilic aesthetic. In both cases, complex geometric and vegetal patterns successively repeat, offering a single decorative solution to different supports (Marinetto Sánchez 2012).

In the fragment at the Museum of Guadalajara, the right panel of the heikhal has a superimposed polylobulated arch over a vegetal background that contains an elaborate rhomboidal pattern formed by a palmette against a red background. The upper left corner has an inscription that frames the central panel and reproduces part of Psalms 27:4: "One thing have I desired of the Lord, that will I seek after; that I may dwell in the house of the Lord all the days of my life" (Figure 15). The pinecone located in the corner of the inscription, as well as the position of the line itself, slightly sloped toward the interior of the ark, corroborates this location in comparison with the synagogues of Córdoba and El Tránsito (Figure 17).

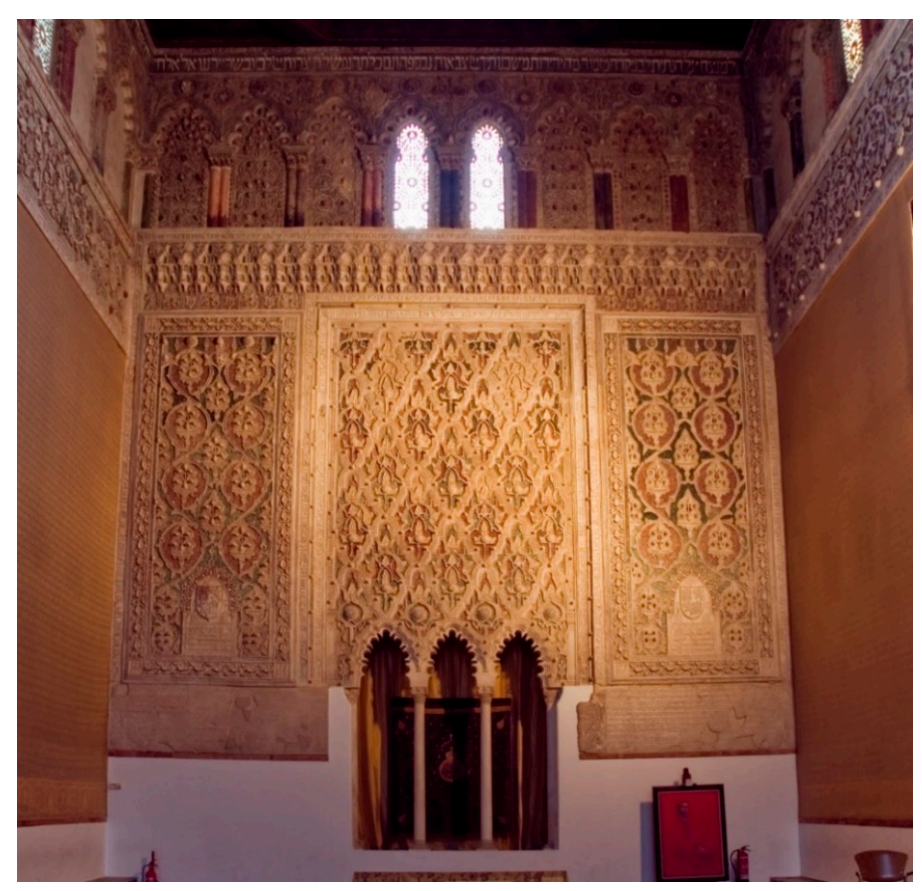

Figure 16. The heikhal of El Tránsito Synagogue. Author's photo.

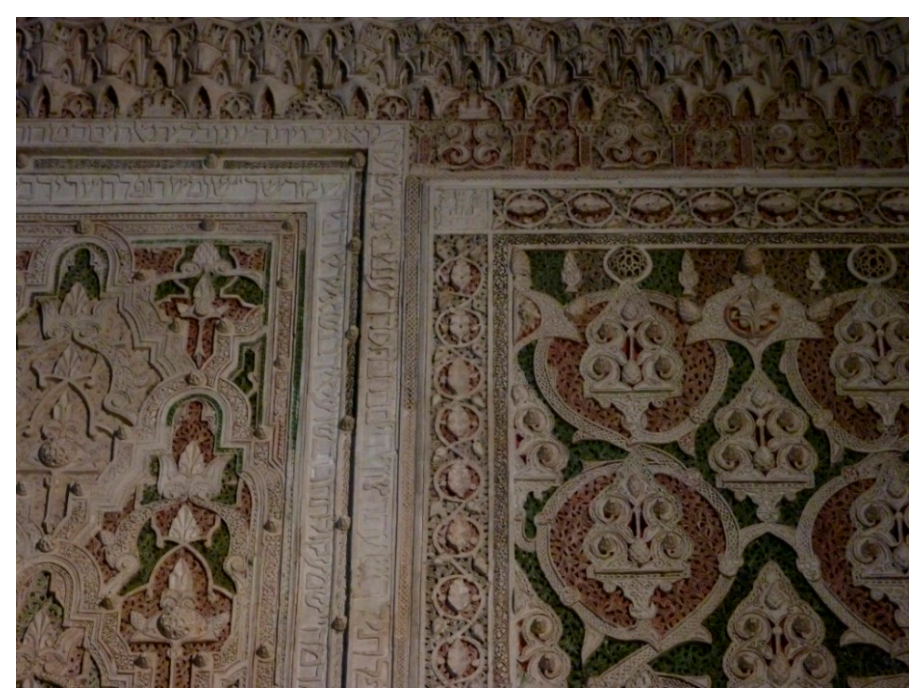

Figure 17. Detail of the heikhal of El Tránsito Synagogue. Author's photo. 
The right panel of the heikhal facade of Molina indicates that the central panel protruded over the two side panels as in the heikhal facade of El Tránsito. By analogy, it is possible to suggest that, to align the composition, the smooth strip of decoration was the decorative start of a muqarna cornice, because the composition of the facade in the synagogues of Córdoba and El Tránsito are crowned by a cornice (Figure 3), although, in the case of Córdoba Synagogue, the side panels protrude over the central one, and the cornice is only over it (Figure 4).

Another piece that may have formed part of the ark decoration is a fragment from a panel that is decorated with a large, rough sebka (rhombus grid) against a vegetal background (Figure 18). It is possible to consider that this fragment was part of the heikhal, because the central panels in the synagogues of El Tránsito and Córdoba also display a sebka. The most striking aspect of this fragment is the thickness of the panel to which it belonged. Such a panel could not have been attached to a simple, smooth wall. Moreover, besides being unnecessary, it would have reduced notably the space in the prayer room, and it would have added weight to the building structure with no justification. The thickness of this panel may be explained by the need to level the northern wall and thus fill in the empty space in the upper part of the central panel in the heikhal, because the lower part would have been left empty to store the Torah scrolls. The upper part of the niche would have been hidden by the thick plaster decoration, creating a surface that allows for the display of the decorative facade.

Other plaster pieces belonging to the synagogue may also be related to the ark. The form of these fragments seems to indicate that they may have belonged to some type of architectural decoration unrelated to the structure of the building itself, because, being plaster, they could not have formed part of any architectural support. Two small pieces are decorated with an acanthus leaf that is rolled up like a volute (Figure 19(1,2)). One of those (labelled in Figure 19(1,1a)) has a smooth side that suggests that it belonged to a corner volute on what seems to have been a small Corinthian-inspired capital (Figure 19). The other piece is a plaster fragment that could have formed part of an arch. The form of the piece suggests that this was part of the intrados and the right impost of an arch (Figure 20). Due to its shape, it was probably embedded in a wall. As is the case for the Synagogue of El Tránsito, it could be possible that the heikhal of Molina also had arches into the heikhal. However, based on the shape of the piece, the arches could have been pointed arches instead of polylobulated ones.

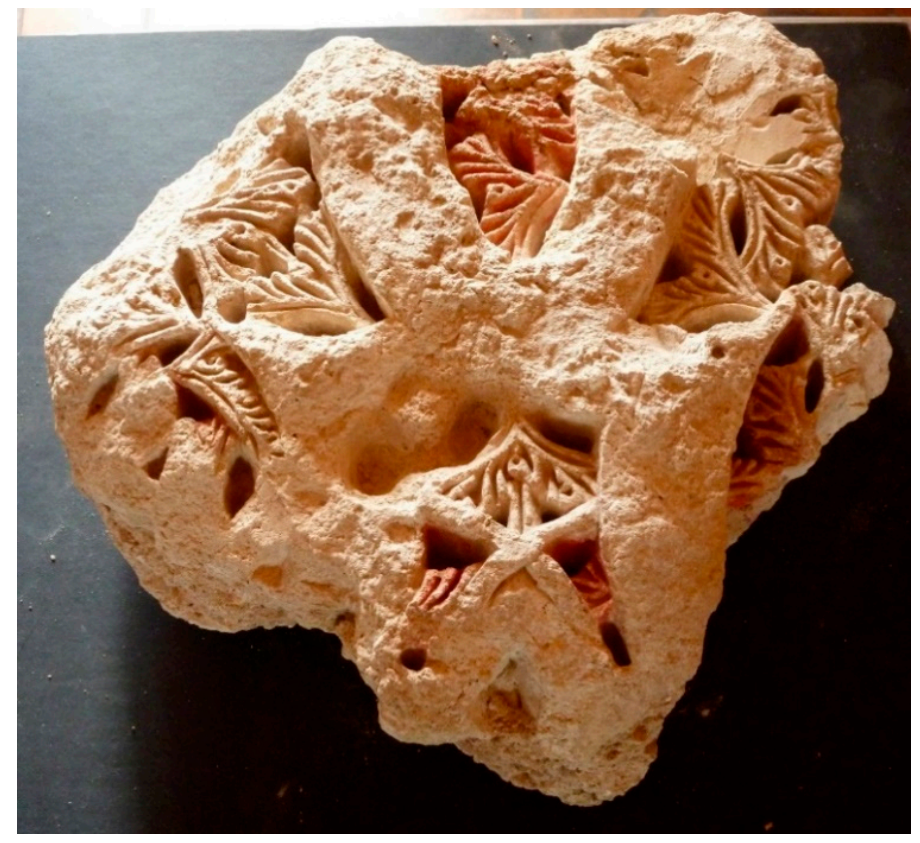

Figure 18. Panel fragment of Molina de Aragón Synagogue. Author's photo. 
Another of the plaster fragments found is quite notable due to its epigraphical remains (Figure 21). The Hebrew letters on this piece are not inside the border; instead, they are organized into two levels. Based on the lines that separate the inscription as if they were brackets, it seems that, originally, there were at least three lines of inscription, although they were likely much longer. The inscription is divided into superimposed lines, as if it were a text on paper, and the lines that form brackets are characteristic of the foundational plaques of the Synagogue of Córdoba and El Tránsito (Figures 4 and 16). For this reason, this fragment may have been part of a foundational inscription that publicly identified the synagogue founder or perhaps the person who financed the redecoration. In this case, the foundational plaque would have been on the heikhal wall, as in the synagogues of El Tránsito and Córdoba.
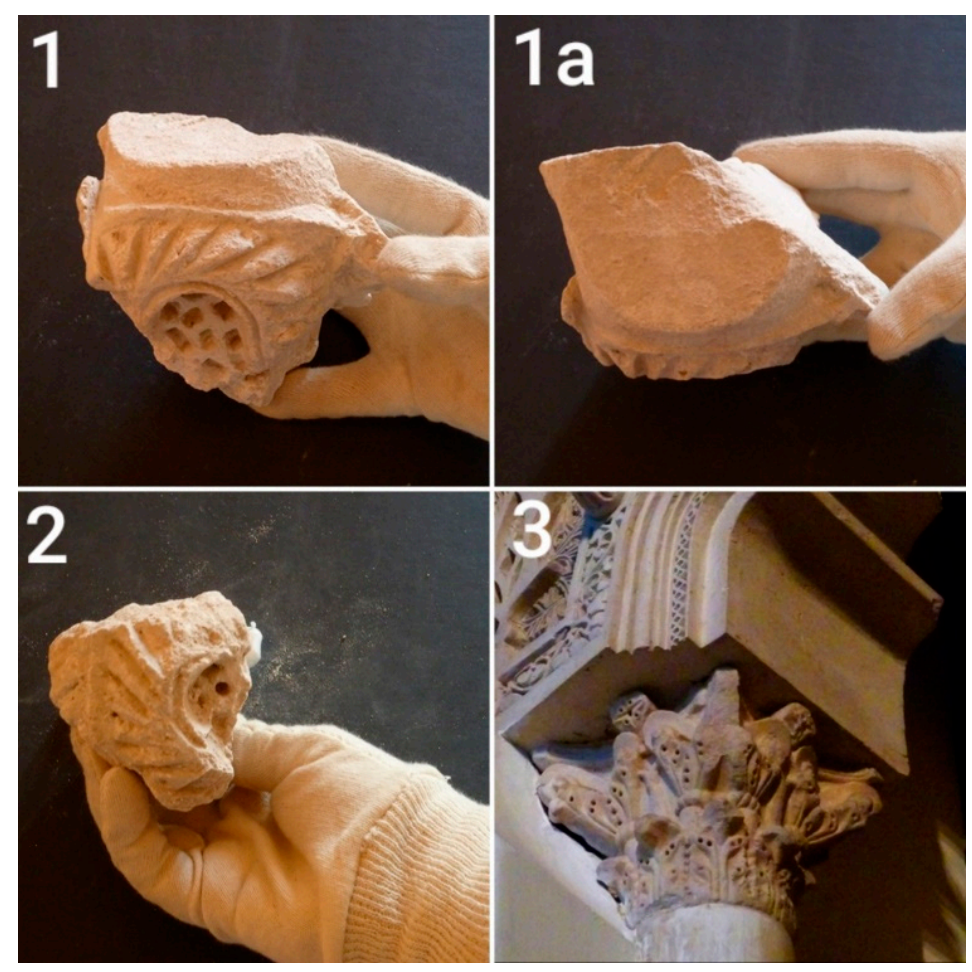

Figure 19. Fragment of a small capital. (1) and (1a) different views of the same piece, (2) fragment of a leaf, (3) small capital from the heikhal of El Tránsito Synagogue. Used by permission

The analysis of the decorative fragments suggests that the synagogue had a heikhal facade divided into three vertical panels in the same style of the fourteenth-century synagogues of El Tránsito and Córdoba. During the fourteenth century, the Synagogue of Molina combined decorative elements from the thirteenth century, such as capitals, with an ark decorated according to the decorative trend of the fourteenth century (Figure 22). The local community of Molina built and refashioned its synagogue in connection and artistic dialogue with other Jewish communities across time. Molina is a unique case that illustrates the transmission of architectural design and decorative models from large Jewish aljamas, such as the ones of Toledo and Córdoba, toward much smaller ones, located far from these important production centers of Jewish culture. 

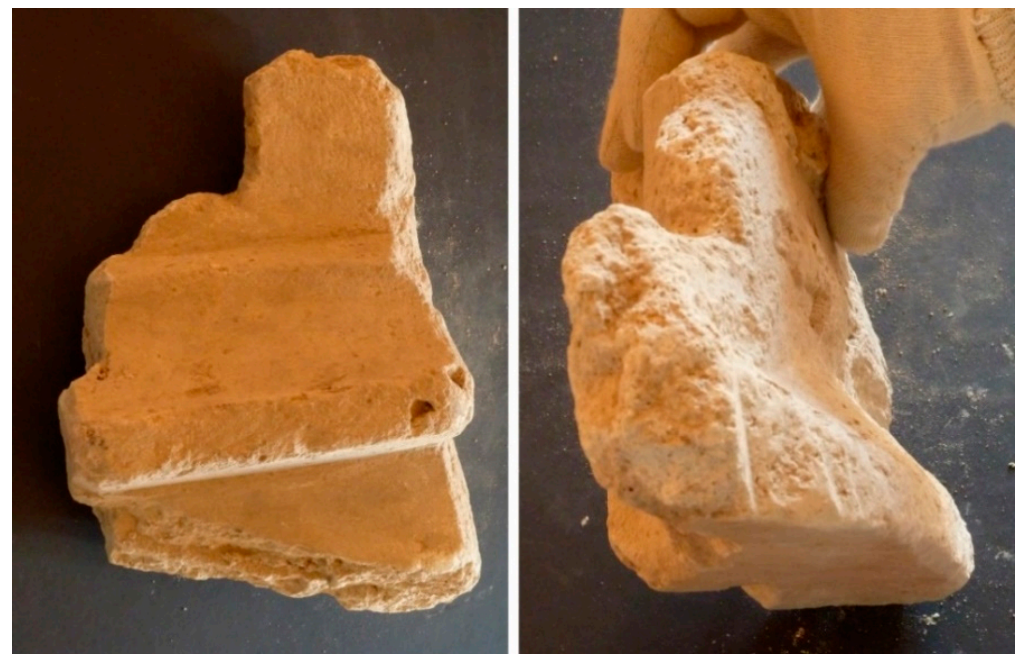

Figure 20. Arch fragment of the Molina de Aragón Synagogue, (left) view of the intrados side, (right) the special form to be embedded from the top of the piece. Author's photo.
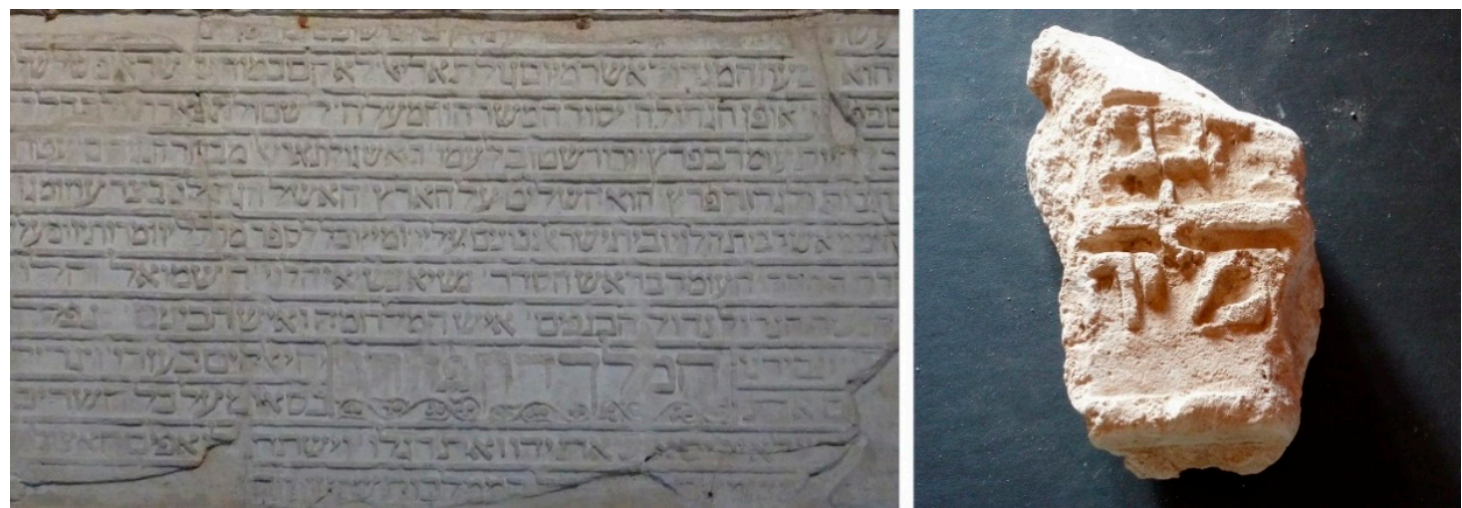

Figure 21. Fragment with epigraphy of Molina de Aragón Synagogue (right) compared with the foundation plaque of El Tránsito Synagogue (left). Author's photo.

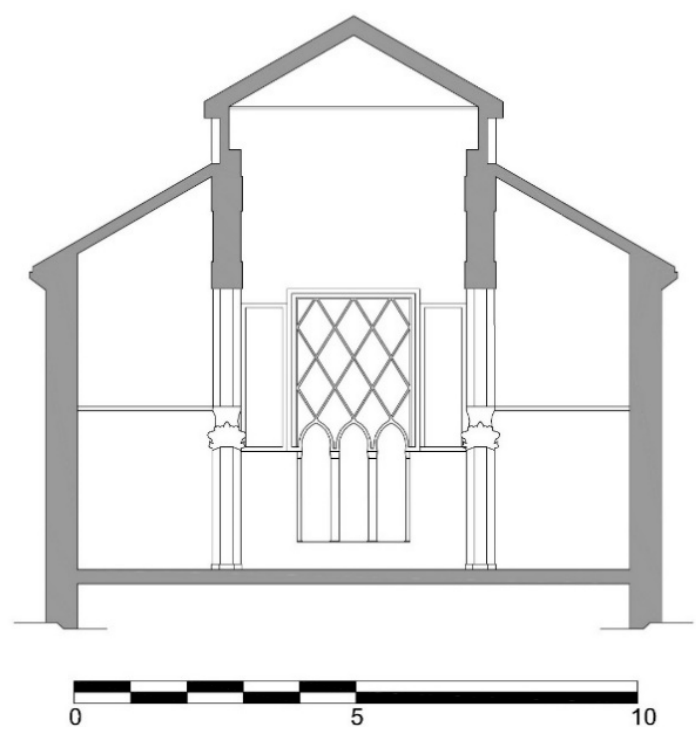

Figure 22. Reconstructed cross section of Molina de Aragón Synagogue. Drawing by Fernando Lechuga. Used by permission. 


\section{Other Decorative Elements}

Many small fragments seem to have formed part of a decorative frieze, as well as panels and windows. The small size and uniqueness of the pieces make it impossible to find the connection between them. Despite that, some of them can be compared to the elements of the decoration in the Synagogues of El Tránsito, Córdoba, and Santa María la Blanca of Toledo.

A small fragment that belonged to a little window that had the form of a rounded arch is particularly remarkable (Figure 23). This piece contains part of the window frame and the latticework made of plants that would have blocked a considerable amount of natural light from the synagogue, thus making ventilation of the building its primary purpose. This unique fragment could have belonged to one of the windows located in the central nave above a decorative frieze, as it is found in the synagogues of Segovia and Santa María la Blanca in Toledo (Figure 24). Two other small fragments contain Hebrew epigraphy. The first, which consists of three pieces, reproduces the Hebrew letters (מבוא), which could refer to Proverbs 8:3 (Figure 25), while the other fragment reads (אתנו) (Figure 26), a word that could refer to Psalms 67:2 (Arenas Esteban and Castaño González 2010).

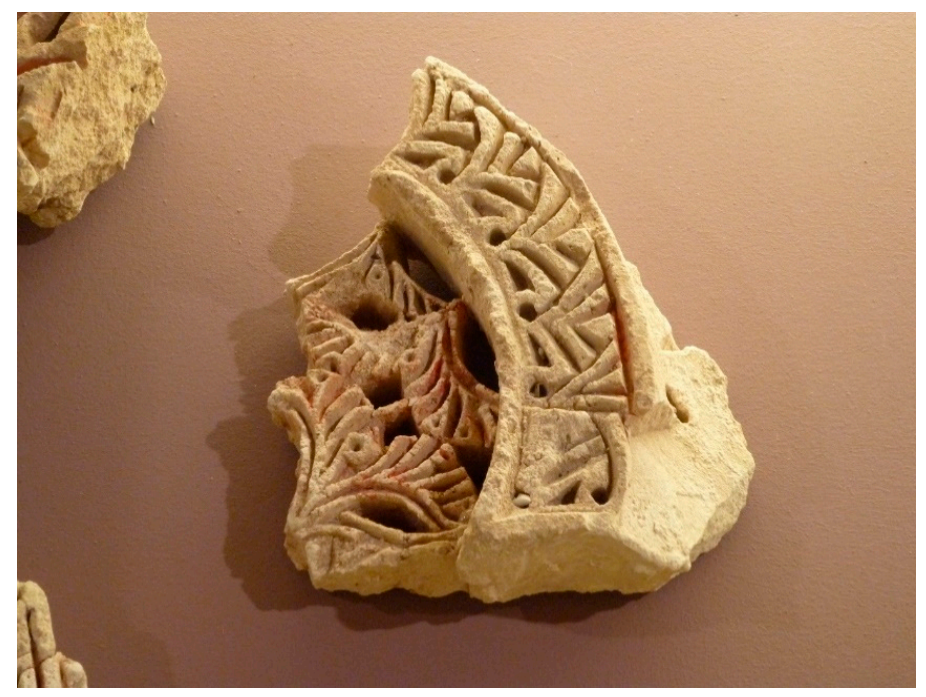

Figure 23. Window latticework fragment, Molina de Aragón Synagogue. Author's photo.

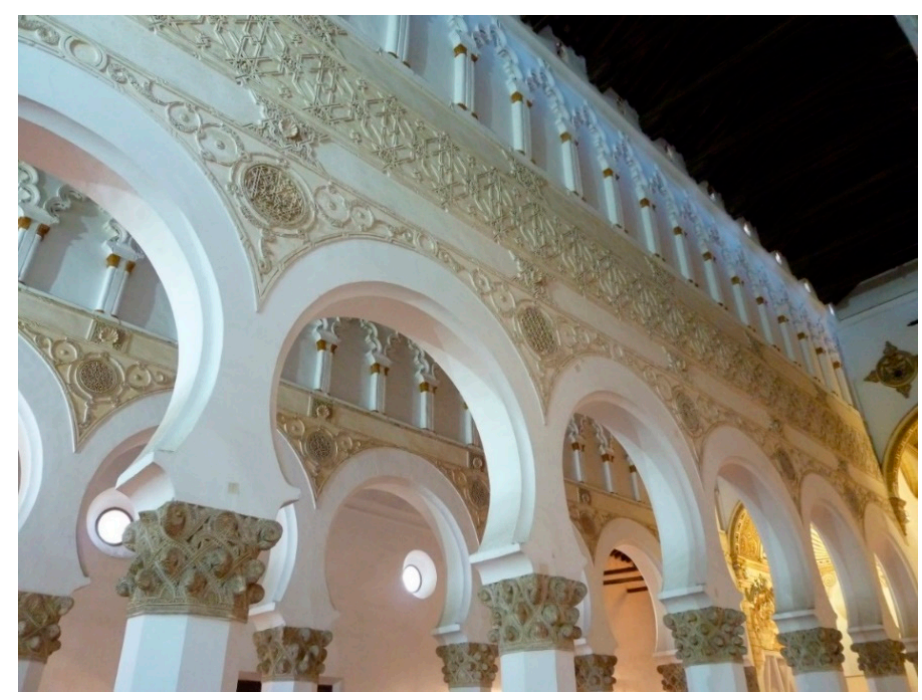

Figure 24. Interior of the Santa María la Blanca synagogue of Toledo. Author's photo. 


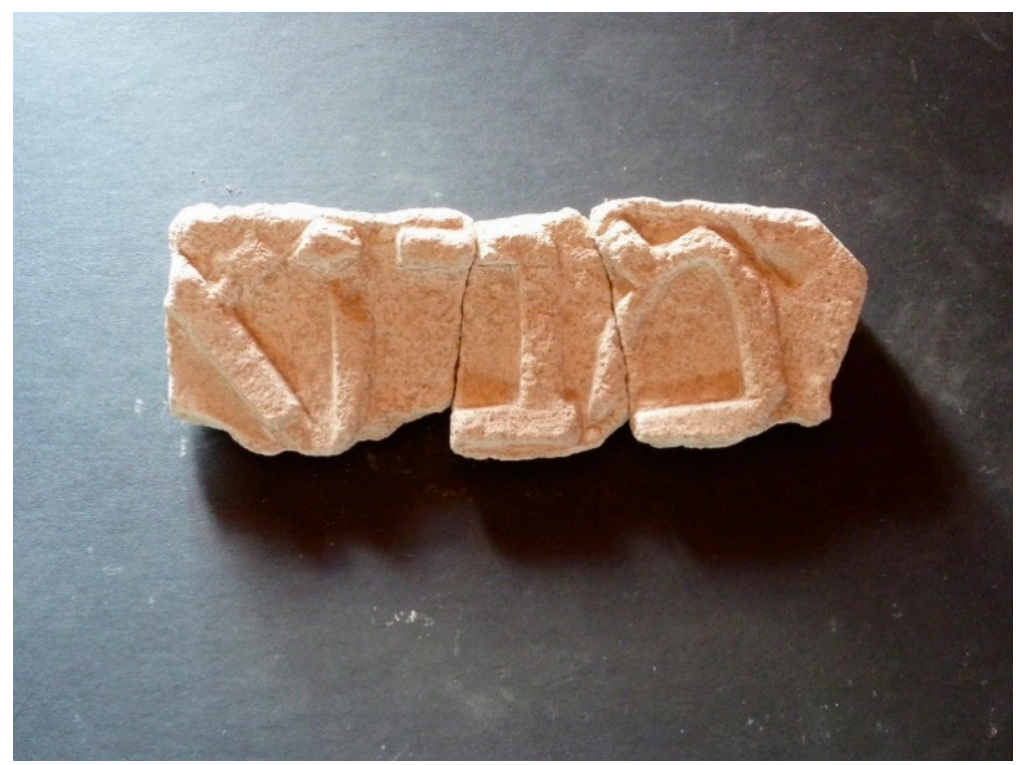

Figure 25. Fragment with Hebrew epigraphy, Molina de Aragón Synagogue. Author's photo.

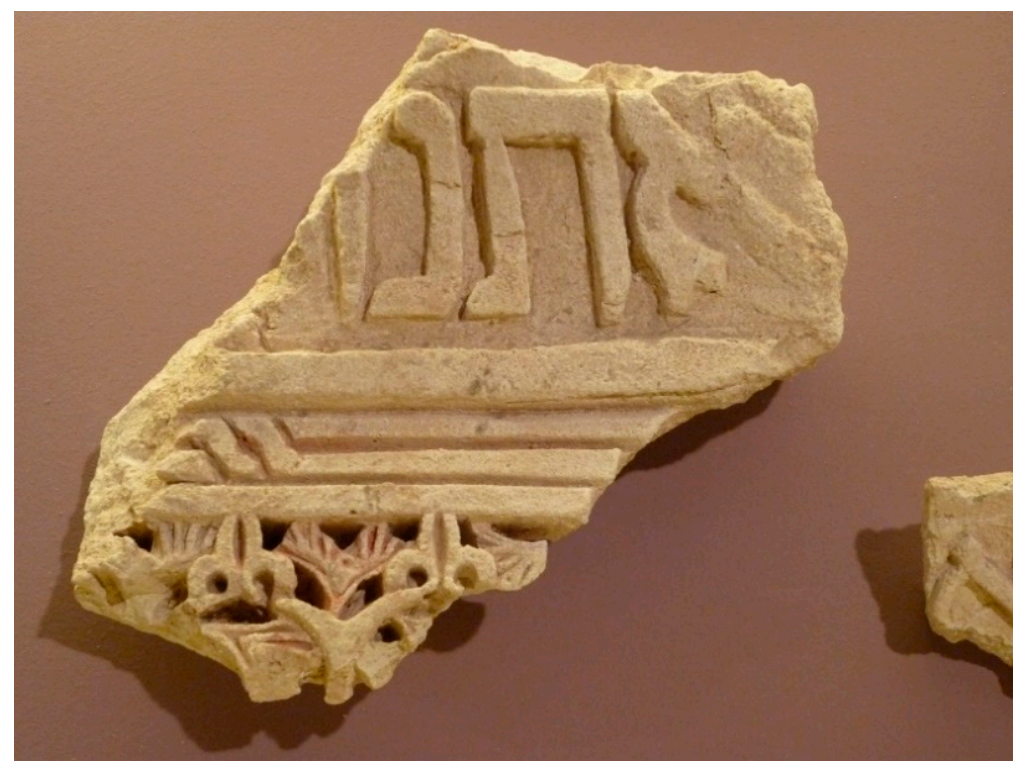

Figure 26. Fragment with Hebrew epigraphy, Molina de Aragón Synagogue. Author's photo.

Another piece is particularly outstanding due to its Arabic epigraphy (Figure 27), as is the case of some religious formulas written in Arabic that can be found on the walls of the synagogues of Córdoba and El Tránsito. This is an example of the Andalusian heritage among the Castilian Jews. ${ }^{18}$ In the Synagogue of Córdoba, Psalm 22:29, written in Arabic on two muqarna panels, decorates the alcove of the tevah, while in the Synagogue of El Tránsito, there is an Arabic inscription that includes the formula "happiness, well-being, glory and honor" encircling the prayer room (Figures 28 and 29).

18 In 1145, the Almohads arrived to the Iberian Peninsula having an impact on the religious context and making the conditions of all the religious minorities in Al-Andalus worse, forcing many Jewish families to settle in northern Christian kingdoms, bringing the Arab culture and language with them. The Andalusian Jews borrowed many cultural elements from the Arabs who inhabited the Iberian Peninsula, contributing a great deal to the intellectual and artistic world of Al-Andalus. Far from forgetting this culture, they kept it alive. During the next two centuries, the prevalence of an Arab cultural substrate was discernible among the Jewish communities of Castile (Muñoz-Garrido 2017b). 


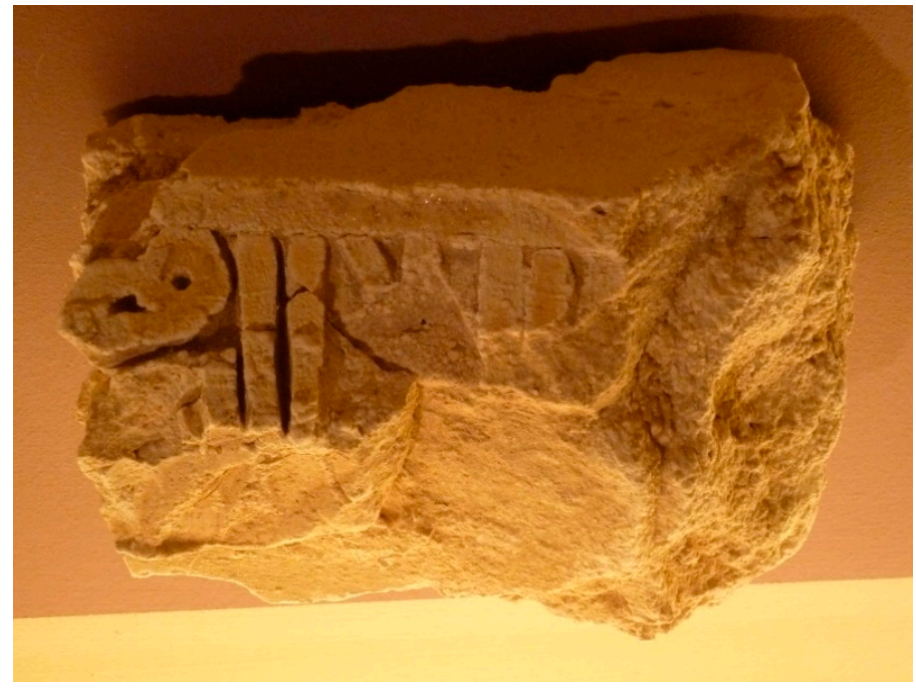

Figure 27. Fragment with Arabic epigraphy, Molina de Aragón Synagogue. Author's photo.

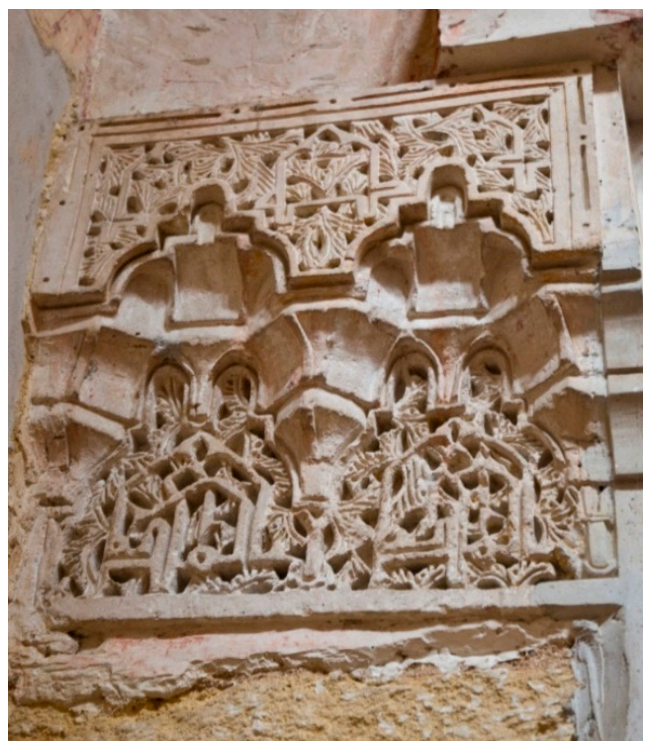

Figure 28. Arabic inscription on a muqarna decoration panel, Córdoba Synagogue. Author's photo.

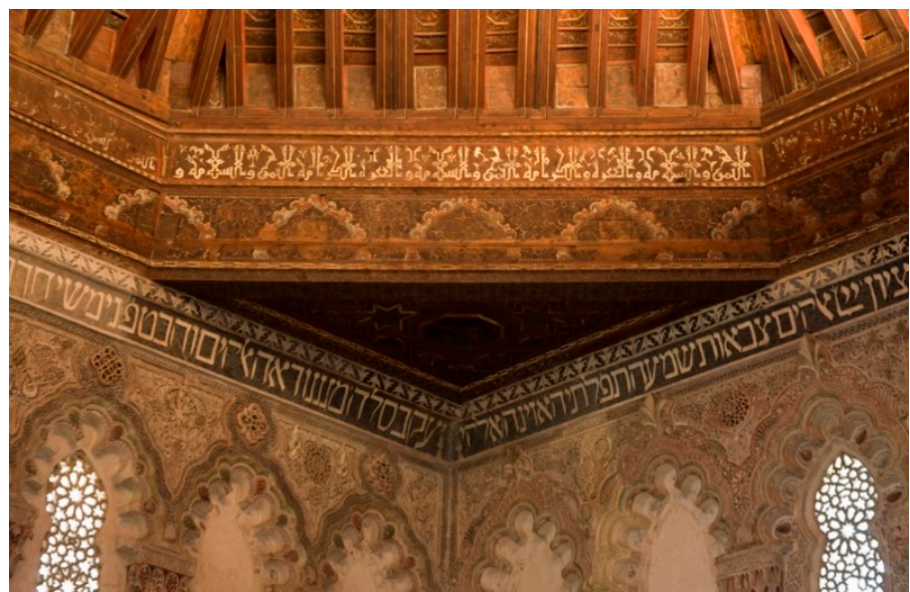

Figure 29. Arabic inscription frieze around the prayer room of El Tránsito Synagogue of Toledo. Author's photo. 
The remains of windows, decorative panels, and lines of epigraphy suggest that the Molina de Aragón Synagogue was extensively decorated and that the ornamentation was not limited to the capitals and the heikhal facade. It is quite possible that all of these decorative remains formed part of the upper section of the synagogue's central nave, as is the case for the Synagogue of Santa María la Blanca of Toledo (Figure 24).

\section{Conclusions}

The archeological remains of the Synagogue of Molina de Aragón are very unique. One of the reasons that explains its singularity is the fact that many of the Iberian Medieval synagogues preserved until the present day are located in big and important cities, whereas Molina is a small town on the border of the Kingdom of Castile. This synagogue is an example of a modest type of synagogue that existed in rural areas. In addition, its internal decoration constitutes a special case; the medieval synagogues preserved until today were founded by important members of the Jewish community who were able to build and decorate the synagogue simultaneously. That is the reason synagogues such as the ones of Córdoba and El Tránsito present a very unitary appearance with respect to their architecture and decoration. On the contrary, the remains of Molina bring to light other type of patronage, more likely to occur in a rural context. The result of this was the construction of a synagogue that happened to be refashioned over time. The Synagogue of Molina was built and decorated in the second half of the thirteenth century, and it was redecorated later on in the fourteenth century, creating an artistic dialogue with others Jewish communities in important cultural centers.

The result was a synagogue with three naves that combined decorative elements from the thirteenth century, including pillar capitals and a heikhal facade in the same line as the decorative trends of the fourteenth century, such as the synagogues of Córdoba and El Tránsito. The primitively decorated capitals, with five different models, were arranged in pairs on the pillars that separated the central nave of the synagogue, as in Santa María la Blanca of Toledo. It also appears that the decoration from the upper part of the central nave was preserved, where a decorative frieze probably ran, also similar to what can be found in the Santa María la Blanca Synagogue in Toledo. The heikhal appears to have been located on the north wall, as suggested by the placement of the tevah and alminbar. The north wall also contains a space that could have been used to hold the Torah scrolls. In the fourteenth century, the synagogue was redecorated, and the north wall was covered with new plaster. The large portion of decoration found with Hebrew inscriptions reveals that the synagogue followed the heikhal facade model used in the Córdoba and El Tránsito synagogues, a model made up of three panels in which the central panel opens to connect the niche holding the ark to the prayer room.

The architecture of the Molina de Aragón Synagogue is lively and attests to a local community that did not allow its place of worship to become old and antiquated. The fourteenth-century redecoration adopted the fashion of the moment. Moreover, the remodeling work done indicates that this house of worship was active for a very long time.

Funding: The research for this essay was carried out under the auspices of the research project Language and Literature of Rabbinic and Medieval Judaism (FFI2016-78171-P), funded by the Spanish Ministry of Science, Innovation and Universities.

Conflicts of Interest: The author declares no conflict of interest.

\section{References}

Arenas Esteban, Jesús A. 2017. El asentamiento de “El Castil de los Judíos” (Molina de Aragón, Guadalajara). Miscelánia de estudios árabes y hebraicos sección hebreo 66: 33-52.

Arenas Esteban, Jesús A, and Juan P Martínez Naranjo. 2004. El Prao de los judíos. Molina de Aragón (Guadalajara). In Investigación arqueológicas en Castilla-La Mancha, 1996-2002. Edited by L. Abad Casal. Toledo: Servicio de Publicaciones de la Junta de Comunidades de Castilla-La Mancha, pp. 437-47.

Arenas Esteban, Jesús A, Juan P Martínez Naranjo, and Teresa Daza Blázquez. 2007. El "Prao de los Judíos" de Molina de Aragón: resultado de siete años de trabajo. In La Mancha. Actas de las I Jornadas (Cuenca 13-17 
de diciembre de 2005). Edited by J. M. Millán Martínez and C. Rodríguez Ruza. Cuenca: Ediciones de la Universidad de Castilla-La Mancha, pp. 705-31.

Arenas Esteban, Jesús A, and Javier Castaño González. 2010. La sinagoga medieval de Molina de Aragón: Evidencia documental y epigráfica. Sefarad 70: 497-508. [CrossRef]

Baer, Yitzhak. 1998. Historia de los judios en la España cristiana. Barcelona: Riopiedras.

Ben-Dov, Meir. 2009. The Golden Age: Synagogues of Spain in History and Architecture. Jerusalén: Urim Publications. Blasco Martínez, Asunción. 1988. La judería de Zaragoza en el siglo XIV. Zaragoza: Instituto Fernando el Católico.

Blasco Martinez, Asunción. 2014. Las fuentes documentales y el estudio de la cultura material hispano judía en el reino de Aragón. In ¿Una Sefarad Inventada? Los problemas de interpretación de los restos materiales de los judios en España. Edited by Javier Castaño. Córdoba: Ediciones El Almendro, pp. 183-220.

Borrás Gualis, Gonzalo. 2004. El mudéjar y la expresión artística de las minorías confesionales en Aragón: mezquitas y sinagogas. In Aragón Sefarad. Zaragoza: Diputación de Zaragoza, pp. 381-92.

Cantera Burgos, Francisco. 1984. Sinagogas Españolas. Madrid: CSIC.

Cantera Burgos, Francisco, and José María Millás Vallicrosa. 1956. Las inscripciones hebraicas de España. Madrid: CSIC.

Cantera Montenegro, Enrique. 1985. Solemnidades, ritos y costumbres de los judaizantes de Molina de Aragón a fines de la Edad Media. In Actas del II Congreso Internacional Encuentro de las Tres Culturas: 3-6 octubre 1983. Toledo: Ayuntamiento de Toledo, pp. 59-88.

Ecker, Heather. 1997. The Conversion of Mosques to Synagogues in Seville: the Case of the Mezquita de la Judería. Gesta 36: 190-207. [CrossRef]

Frishman, Martin. 1994. Islam and the form of the mosque. In The Mosque: History Architectural Development and Regional Diversity. Edited by Martin Frishman and Khan Hasan-Uddin. London: Thames \& Hudson Ltd., pp. 17-41.

Gallardo Carrillo, Juan, and José A. González Ballesteros. 2009. La judería del castillo de Lorca en la baja Edad Media. Estudio arqueológico. Murcia: Ediciones Tres Fronteras.

García Sandoval, Juan. 2009. El resplandor de las Lámparas de vidrio de la sinagoga de Lorca. In Lorca, luces de Sefarad. Murcia: Ediciones Tres Fronteras, pp. 260-303.

Gerber Satlow, Jane. 2012. The World of Samuel Halevi: Testimony from the El Transito Synagogue of Toledo. In The Jew in Medieval Iberia, 1100-1500. Edited by Jonathan Ray. Boston: Academic Studies Press, pp. 33-59.

Gil Delgado, Oscar. 2013. Una sinagoga desvelada en Sevilla: estudio arquitectónico. Sefarad 73: 69-96. [CrossRef] Hernández Pardos, Antonio. 2019. La antigua Sinagoga de Hijar, claves de un monumento excepcional. Teruel: Acrótera. Kogman-Appel, Katrin. 2011. Another Look at the Illustrated Sephardic Haggadot: Communal and Social Aspects of the Passover Holyday. In Actes del Simposi Temps i espais de la Girona jueva. Girona: Patronat Call de Girona, pp. 81-101.

Krinsky, Carol Herselle. 1985. Synagogues of Europe: Architecture, History, Meaning. New York: The Architectural History Foundation.

Lloveras Chavero, María José. 2008. Excavacions a la plaça dels Jueus de Besalú (Garrotxa). Tribuna d'Arqueologia, 289-308.

Mann, Vivian B. 2004. Caminos hacia el arte judío español. In Aragón Sefarad. Zaragoza: Diputación de Zaragoza. Ibercaja, obra social y cultural, vol. 1, pp. 371-80.

Mann, Vivian B. 2010. Jews and Altarpieces in Medieval Spain. In Uneasy Communion: Jews, Christians, and the Altarpieces of Medieval Spain. Edited by Vivian B. Mann. Nueva York: Mobia, pp. 76-129.

Mann, Vivian B. 2017. Decorating Synagogues in the Sephardi Diaspora: The role of Tradition. In Synagogues in the Islamic World: Architecture, Design, And Identity. Edited by Mohammad Gharipour. Edinburgh: Edinburgh University Press, pp. 207-25.

Marinetto Sánchez, Purificación. 2012. El uso del tejido y su decoración en los palacios de la Alhambra. In $A$ La Luz de la Seda. Madrid: TF Editores, pp. 19-31.

Muñoz-Garrido, Daniel. 2016. "Felicidad, bienestar, gloria y honor" la imagen pública que Samuel ha Leví proyectó en la Sinagoga del Tránsito. Sefarad 76: 97-120. [CrossRef]

Muñoz-Garrido, Daniel. 2017a. Las sinagogas de Córdoba y del Tránsito. Arte y simbología. Córdoba: Ediciones el Almendro. 
Muñoz-Garrido, Daniel. 2017b. The prevalence of Islamic Art amongst Jews of Christian Iberia: Two Fourteenth-century Castilian Synagogues in Andalusian Attire. In Synagogues in the Islamic World, Architecture, Design, and Identity. Edited by Mohammad Gharipour. Edinburgh: Edinburgh University Press, pp. 127-44. Palomares Sánchez, Bárbara. 2009. Antigua Sinagoga de Santa María la Blanca. Córdoba: Ediciones el Almendro. Palomero Plaza, Santiago. 2002. Sinagoga de Cuenca. In Memoria de Sefarad. Madrid: SEACEX, pp. $252-53$.

Passini, Jean. 2011. La judería de Toledo. Toledo: Ediciones del Sofer.

Piqueras Haba, Juan. 2004. Los Judíos y el vino en España siglos XI-XV. Una geografía histórica. Cuadernos de Geografía 75: 17-41.

Prieto Vázquez, Germán. 1998. Arqueología de Santa María la Blanca. In El Legado Material Hispanojudío. Edited by López Álvarez, Ana María and Izquierdo Benito Ricardo. Cuenca: Ediciones de la Universidad de Castilla La Mancha, pp. 348-62.

Riera i Sans, Jaume. 2006. Els poders públics i les sinagogues: Segles XIII-XV. Girona: Patronat Call de Girona.

Roth, Cecil. 1948. Las inscripciones históricas de la Sinagoga del Tránsito de Toledo. Sefard 8: 4-22.

Ruiz Hernando, José Antonio. 1991. La Sinagoga de Ibañez de Segovia, en Segovia. Estudios Segovianos 88: 139-58. Ruiz Souza, Juan Carlos. 2002. Sinagogas sefardíes monumentales en el contexto de la arquitectura medieval hispana. In Memoria de Sefarad. Madrid: SEACEX, pp. 225-39.

Ruiz Souza, Juan Carlos. 2009. Toledo entre Europa y al-Andalus en el siglo XIII. Revolución, tradición y asimilación de las formas artísticas en la Corona de Castilla. Journal of Medieval Studies 1: 233-71. [CrossRef]

(C) 2020 by the author. Licensee MDPI, Basel, Switzerland. This article is an open access article distributed under the terms and conditions of the Creative Commons Attribution (CC BY) license (http://creativecommons.org/licenses/by/4.0/). 